Late Classical and Hellenistic Furniture and Furnishings in the Epigraphical Record Author(s): Dimitra Andrianou

Source: Hesperia: The Journal of the American School of Classical Studies at Athens, Vol. 75, No. 4 (Oct. - Dec., 2006), pp. 561-584

Published by: The American School of Classical Studies at Athens

Stable URL: http://www.jstor.org/stable/25068004

Accessed: $31 / 03 / 2014$ 04:15

Your use of the JSTOR archive indicates your acceptance of the Terms \& Conditions of Use, available at http://www.jstor.org/page/info/about/policies/terms.jsp

JSTOR is a not-for-profit service that helps scholars, researchers, and students discover, use, and build upon a wide range of content in a trusted digital archive. We use information technology and tools to increase productivity and facilitate new forms of scholarship. For more information about JSTOR, please contact support@jstor.org. 
HESPERIA 75 (2006)

Pages $56 r-584$

\section{LATE CLASSICAL AND HELLENISTIC FURNITURE AND FURNISHINGS IN THE EPIGRAPHICAL RECORD}

1. Andrianou 2006. Both studies draw upon my doctoral thesis on furniture and furnishings in Late Classical and Hellenistic Greece (Andrianou 2003). I am grateful to the American School of Classical Studies at Athens for facilitating my research with a Jacob Hirsch Fellowship, 2003-2004, and to Miltiades B. Hatzopoulos, Argyro Tataki, and Sophia Zoumbaki (National Hellenic Research Foundation) and Stephen Tracy (American School of Classical Studies at Athens) for various suggestions on an earlier version of this study. I am also indebted to the two anonymous reviewers of
This article reviews the epigraphical evidence for furniture and furnishings from Late Classical and Hellenistic Greece, with particular attention to the furniture recorded in the treasure lists of Greek sanctuaries, and in the inscriptions recording loans, mortgages, and other commercial transactions involving property, between the late 4 th and 1st centuries B.c. The principal goals of the study are to collect the types of furniture and furnishings mentioned in the inscriptions; to examine the vocabulary used to describe them and, where possible, to determine their value; and to discuss the purpose and significance of the furniture found in ancient Greek sanctuaries, whether used for display, storage, or as mobilier du culte.

The present study is a supplement to my survey of the archaeological evidence for furniture and furnishings in Late Classical and Hellenistic Greece, published earlier in this volume of Hesperia. ${ }^{1}$ That article, which focused on the remains of furniture recovered in excavations, showed that a great deal can be learned from a careful examination of the archaeological evidence, but it also revealed that the quantity of excavated material is relatively small, and that the majority of it comes from Macedonian funerary contexts. The epigraphical evidence, which forms the basis for the present study, helps to fill out this picture and provides valuable information about furniture and furnishings unattested in the archaeological record. The two studies work together to fill a gap in our current understanding of the multiple functions of furniture in the ancient Greek world, from domestic accoutrements to sacred dedications.

(C) The American School of Classical Studies at Athens
Hesperia for their helpful comments and additional bibliography. All have helped me remedy omissions and errors in the translation and interpretation of the inscriptions. Translations of ancient sources are my own unless otherwise indicated. 
The purpose of this article is to present the evidence for furniture and furnishings found in the commercial inscriptions and sacred treasure lists of the Late Classical and Hellenistic periods. ${ }^{2}$ I have three main goals: to review the types of furniture attested in the epigraphical record and the vocabulary used to describe them; to determine the value of domestic furniture and furnishings in loan agreements, house purchases, and other transactions involving debt and credit; and to analyze the purpose and significance of furniture recorded in Late Classical and Hellenistic sanctuaries, whether used for storage, as mobilier du culte, or as objects intended for display.

The discussion that follows rests chiefly upon inscriptions found in Attica, Delos, and Macedonia. ${ }^{3}$ From these areas, between the 4th and 1 st centuries B.C., come most of the records of sales or leases of property, and most of the surviving inventories of furniture and other votive offerings dedicated in temples and sanctuaries. I have therefore chosen to concentrate on this large and well-published body of material, without, however, excluding evidence from other sites when it is available. ${ }^{4}$

\section{FURNITURE IN AUCTION, LOAN, AND MORTGAGE INSCRIPTIONS}

The earliest, and among the most extensive, epigraphical records of furniture are the so-called Attic Stelai, the accounts of the confiscated property of Alcibiades and his followers, convicted of profaning the Eleusinian Mysteries and mutilating the Herms in 415 or 414 B.c. ${ }^{5}$ The Stelai record movable domestic objects and land in Attica, Euboia, Eretria, Thasos, Abydos, and the Troad. Although these accounts fall outside the chronological limits of the present study, they provide valuable supplementary evidence for the names and prices of the furniture attested in other sources. ${ }^{6}$ Some

2. I use the term "furniture" in the prevailing modern sense of movable domestic objects, either useful or ornamental. Chairs, beds, tables, containers and shelves used for storage, basins and bathtubs, as well as grinders, troughs, mortars and pestles, and other objects used in working spaces of the house, all fall into the category of domestic furniture. The term "furnishings" includes materials such as pillows, mattresses, and other bedding, which cover furniture in order to increase comfort; as well as curtains, valances, and paintings, which drape and decorate house interiors.

3. I have included the Macedonian evidence with that from central and southern Greece and the Aegean islands. Although this is not the place to argue the question of Macedonian ethnicity, the archaeological record demonstrates that the same types of furniture were used throughout the region of what is now modern Greece, and recent studies of the Macedonian language point in the same direction: see, e.g., Dubois 1995; Brixhe and Panayotou 1994; $O C D^{3}$, pp. 905-906, s.v. Macedonian language (O. Masson).

4. In preparing the present study I have relied on a thorough search of the epigraphical sources using the Packard Humanities Institute CD-ROM PHI 7 (compilation 1991-1996) and SEG, together with the latest discussions of the temple inventories by Diane Harris (Athenian Acropolis), Tullia Linders (Artemis Brauronia), Sara Aleshire (Athenian Asklepieion), and Richard Hamilton (Delos). None of these authors focuses specifically on furniture, but their work is nevertheless extremely useful, since they provide updated lists of objects, new readings, and other corrections to the earlier literature.
A selection of the evidence is cited in the notes; full appendices, with complete lists of the furniture recorded in the inscriptions, will appear in my forthcoming book on ancient Greek furniture (in preparation).

5. Agora XIX, p. 70, P1. Systematic discussions of the Stelai can be found in Pritchett 1953 and 1956, together with Amyx 1958. See also Lewis 1966.

6. The prices are indicative of the value of the furniture only within the context of an auction taking place in 5th-century Athens. They are certainly not to be compared with prices recorded in sales documents, and because of the "bargain basement" nature of the auction, they probably do not reflect actual values. Without evidence of a similar kind from elsewhere in Greece, we are unable to compare the value of furniture at different sites. 
of the types of furniture mentioned in the sacred inventories of the 4th and 3rd centuries B.c. are also found in the Attic Stelai, and for that reason the evidence they provide will be noted where appropriate.

In Greece during the Late Classical and Hellenistic periods it was customary for a man who borrowed a large sum of money to pledge some property as security for the repayment of his loan. A number of inscriptions recording loans with sureties and deeds of sale (ڤ்vท́, ov̉ví) have survived, particularly from the territories of Olynthos and Tenos. ${ }^{7}$ Although houses (oiki $\alpha \mathrm{l}$ ) themselves are explicitly mentioned in these documents, there is very little reference to specific types of furniture sold or rented together with the houses, and absolutely no reference to furniture transacted separately. Nevertheless, the wording of these inscriptions is worth discussing briefly.

The evidence from both Olynthos and Tenos is grouped under Finley's

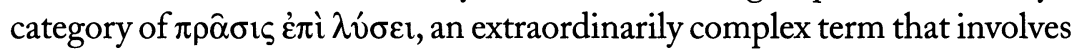
interest payments and property put forth as security. ${ }^{8} \mathrm{It}$ is a hybrid form of transaction that probably falls between sale and hypothecation, since the property that served as security could be bought back by the debtor.

A surety consisting of "the whole property" ( $\tau \varepsilon \hat{\imath}$ oikícı ö $\lambda \varepsilon \imath$ ) is attested in a loan inscription of 352/1 B.c. from Olynthos. ${ }^{9}$ The value of the loan is 4,500 drachmas. It is not clear what "the whole property" means, but two interpretations are possible: either the entire house (with all the separate rooms, including the work areas), or the house along with its furniture. The second possibility is very attractive, but cannot be proven.

It would be interesting to know whether the price paid for these houses included the furniture, but there is no evidence on which to base an answer to the question one way or the other. Furthermore, the size of each house and its location within the city is unknown. The prices of the houses vary widely, and in many cases the reading of an inscription is disputed. In an inscription found in the area of the Villa of Good Fortune at Olynthos, for example, a certain Ainetos paid 400 drachmas for a house. The price for a house elsewhere in Chalkidike was 300 drachmas, ${ }^{10}$ another in Olynthos may have cost 203 drachmas, ${ }^{11}$ and yet another 4,000 drachmas. ${ }^{12}$

More information about furniture can be found in a well-preserved inscription from Tenos, dated to around 300 в.c. ${ }^{13}$ This extensive document records sales of land and houses, loans, and dowries, and shows that the value of houses was roughly the same in Delos, Tenos, and Athens at the beginning of the 3rd century. Forty-seven contracts in total are recorded, all dated to the time of the archon Ameinolas. Certain parts of the house are singled out in the contracts: the $\theta \dot{v} \rho \alpha$, the $\mu \varepsilon \tau \varepsilon \dot{\varepsilon} \omega$ s, $_{\text {, }}$

7. Olynthos: Robinson 1928; 1931, pp. 42-53; 1934, pp. 124-130; 1938, pp. 47-56. Some of the inscriptions have been restudied by Hennig (1987), Hatzopoulos (1988, pp. 58-61), and recently by Giouni (1991, with earlier bibliography). Tenos: IG XII 5872 and 873; discussed in Ténos II, pp. 51-84.

8. Finley 1952 , pp. $31-37$, and Harris 1988 provide thorough discussions of the problems involved in this terminology. The phrase attested in the horoi

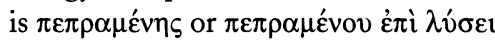
(Agora XIX, pp. 40-47, H84-H113).

9. Olynthus II, p. 110; Hatzopoulos 1988, pp. 58-59 (SEG XXXVIII 637).

10. Wilhelm 1974, vol. 1, pp. 60-62, no. 8 (= SBWien 166 [1911], pp. 4244). The inscription is now believed to be from Arnaia, not Amphipolis
(Hatzopoulos 1988, p. 59).

11. Robinson 1928, pp. 227-230; SEG XXXVII 568, 571. The reading of the price is disputed. The currency used is the drachma, not the stater.

12. Olynthus II, p. 101.

13. IG XII 5 872. The inscription is discussed in Ténos II, pp. 51-84 (SEG XL 687). 


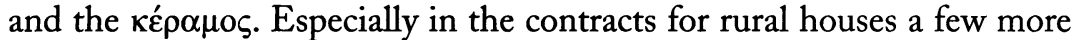
specific items, including furniture, are sometimes mentioned: $\pi 1 \theta \varepsilon \omega ́ v$, ővo $\varsigma$

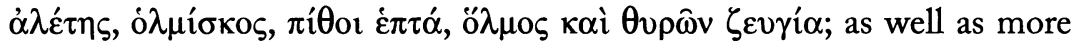

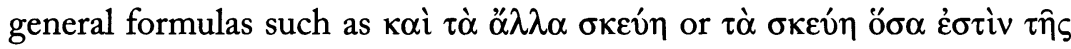
$\gamma \varepsilon \omega \rho \gamma^{\prime} \alpha \varsigma$. The phrase $\tau \dot{\alpha} \alpha \alpha \lambda \lambda \alpha \sigma \kappa \varepsilon v i \eta$ probably refers to all the furniture, and in this context more specifically to the agricultural furniture and tools (mortars, pithoi, etc.). ${ }^{14}$

Another group of inscriptions are the öpor, the large stone markers that indicated the nature of the lien on the property and warned third parties that the man who had pledged the property as security was not free to sell it or otherwise alienate it until the loan was repaid. ${ }^{15}$ Two öpor, one from Naxos and the other from Amorgos, mention furniture that was legally encumbered and not fully at the disposal of the proprietor. The Naxian inscription, dated around 300 B.c., states that the house secured 1,000 drachmas of the dowry and the furnishings a further $500 .{ }^{16}$ The text

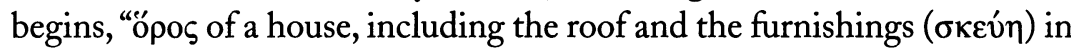

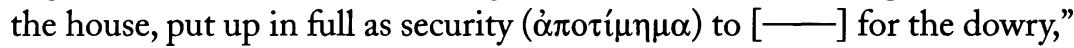
but the following monetary allocation ignores the roof, possibly because it was considered part of the furnishings. ${ }^{17}$ The low figure of 500 drachmas for furniture and furnishings chimes with the auction prices recorded for plain furniture a century earlier in the Attic Stelai. The inscription from Amorgos, dated to the 3rd century B.c., lists among the encumbered prop-

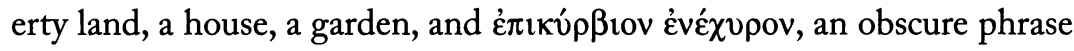
often translated as "recorded pledges."

Finley observes that "when we study land and credit in Athens, the normal link between the two all through the classical period, hypothecation, is an institution limited largely to men of property acting in non-economic capacities." ${ }^{19}$ For some citizens, however, this credit relationship was not available; in such cases a debtor might "pawn his pots and pans and his wife's jewelry [and his furniture and furnishings too, one might add] without destroying his ability to repay." ${ }^{20}$ In other words, "personal possessions are pawned and realty is hypothecated," depending on the type of transaction, the debt, and other unknown factors. ${ }^{21}$

In any case, it is possible, as Finley notes, that "a creditor who accepts furniture as security for a debt, would normally insist on immediate possession." ${ }^{22}$ This might have been the reason why furniture is not often listed in such inscriptions. On the other hand, debtors could take advantage of the portability of furniture and furnishings: in Demosthenes' speech against Onetor, a house is put up as security and the debtor is accused of running off with the furniture (Dem. 30.28). Similarly Lysias, in his speech on the property of Aristophanes, tells the jury that "in all other cases where you have confiscated the property, not merely have you had no sale of furniture, but even the doors were torn away from the apartments; whereas we, as soon as the confiscation was declared and my sister had left the place, posted a guard in the deserted house, in order that neither door-timber nor utensils nor anything else might be lost" (Lys. 19.31). ${ }^{23}$

The fragmentary evidence for domestic furnishings leaves open the questions of the role of property and the meaning of wealth in Late Clas-
14. For the meanings of the word

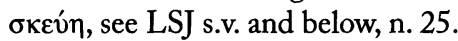

15. For a thorough discussion of öpot, see Fine 1951.

16. IG XII suppl. 195, lines 6-8; Finley 1952, p. 163, no. 156. Here

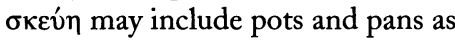
well as house-gear.

17. Trans. Finley 1952 , p. 51 . From inscriptions of sanctuary leases it is known that tenants were to take with

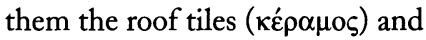
the doors and door frames ( $\theta \dot{0} \rho \alpha \varsigma$, $\theta 0 \rho \omega ́ \mu \alpha \tau \alpha)$ : cf. Kent 1948.

18. IG XII 7 58, line 5; Finley 1952 p. 121 , no. 8 , and pp. $218-219$, n. 81.

19. Finley 1952, p. 87.

20. Finley 1952, p. 56; cf. Ar. Eccl. 753-755, cited by Finley on p. 87.

21. Finley 1952, p. 55.

22. Finley 1952, p. 72.

23. Trans. W. R. M. Lamb, Cambridge, Mass., 1930. 
sical and Hellenistic Greece. As noted above, documents that record the sale prices of houses generally do not indicate whether the furniture was sold together with the building or whether it increased the selling price significantly. To understand the relationship between furniture and wealth, one must look to the ancient authors.

Xenophon in the Memorabilia enumerates the conventional constitu-

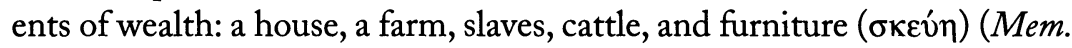
2.4.2) ${ }^{24}$ The same author in Poroi writes that "when someone possesses enough furniture and furnishings (" $" \pi \iota \pi \lambda \alpha$ ) for his house, he would not buy more" (Por. 4.7).$^{25}$ This statement has often been interpreted to mean that "furnishings are wealth as objects of use and display, not in the productive sense of capital goods." ${ }^{26}$ Similarly, Plutarch, when discussing what property should be sold off when cash must be raised, mentions the disposal of silver plates and other "unnecessary items" of precious metal (Mor. 828a).$^{27}$

One cannot generalize from these statements, however, since it is not clear, first, how much movable property even the wealthiest possessed, and second, to what extent furniture was considered a domestic "luxury." There are references to inherited wealth in ancient texts: Demosthenes, for example, mentions some cups and a gold wreath as part of an ancestral inheritance (Dem. 53.9) ${ }^{28}$ In another passage, he lists "a house worth three thousand drachmae, furniture, plate, his mother's jewelry, apparel, and ornaments, worth in all ten thousand drachmae, and eighty more minae in silver kept in the house" (Dem. 27.10). ${ }^{29}$ In a more abstract manner, Lysias notes that "even people credited with long established wealth may fail to produce any [personal effects] that are of value: for at times, however much one may desire it, one cannot buy things of the sort that, once acquired, will be a permanent source of pleasure" (Lys. 19.30). ${ }^{30}$

The archaeological evidence from the vast majority of excavated houses, on the other hand, indicates modestly furnished interiors with only the necessary amount of wooden furniture used in everyday life. ${ }^{31}$ Furniture

24. Cf. also Isae. 11.43 (on inheritance).

25. The translation of the words $\sigma \kappa \varepsilon u ́ \eta$ and "̌ $\pi \mathrm{\imath} \pi \lambda \alpha$ is difficult. I believe that in the context of the oikos the meaning is essentially the same and both terms refer to "movable house-

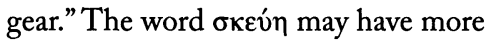
nuances when accompanied by certain

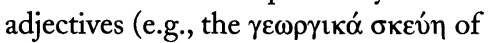
the Tenos inscription, discussed above, pp. 563-564 and n. 13). The word है $\pi \mathrm{\imath} \pi \lambda \alpha$ is epigraphically uncommon: it is attested in an inscription from Larisa, dated to the 1st century A.D. (Arvanitopoulos 1910, pp. 354-361); and in $I G \mathrm{II}^{2} 412$, line 12 (SEG XXXII 81), of the 4th century B.c. In Xenophon in particular, according to Gauthier, $\varepsilon^{\prime} \pi \mathrm{\imath} \pi \lambda \alpha$ is to be translated as "utensils and provisions that are necessary for house-life" (Gauthier 1976, p. 124). This translation is based on a long list of unlike objects grouped as ह̌ $\pi \mathrm{\imath} \pi \lambda \alpha$ by Xenophon in Oec. 9.6-8. An understanding of the nuances requires a thorough examination of the texts, which I hope to present in a separate study (in preparation).

26. Finley 1952, p. 53.

27. The items mentioned are éк $\pi \dot{\omega}$ -

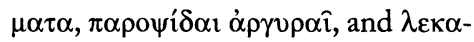

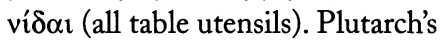
treatise on borrowing is influenced by Plato, especially the Laws, and does not represent the practice of the time. In any case, it is evident that by the 1st century A.D. people were collecting useless items for their tables, beds, and vehicles (Plut. Mor. 828b, 830e, 831f).

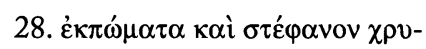

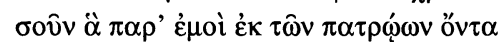

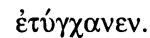

29. Trans. A. T. Murray, Cambridge, Mass., 1939 (adapted). ह̌ıı $\delta$ ' oikíav

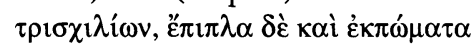

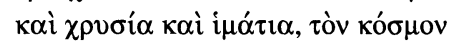

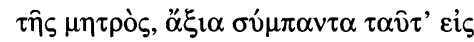

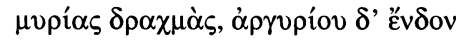

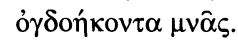

30. Trans. W. R. M. Lamb, Cambridge, Mass., 1930. '่ $\lambda \lambda$ ' ov̉ $\delta$ ' oi

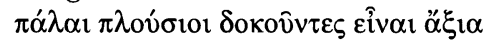

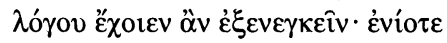

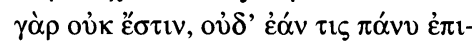

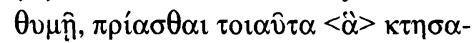

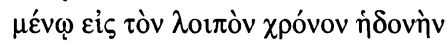
پ̀v $\pi \alpha \rho \varepsilon ́ \chi 01$.

31. Andrianou 2006, pp. 258-261. 
must have been portable and easily moved around, inside or outside the house, according to need. "Luxurious" furniture, such as the items excavated in 4th-century Macedonian tombs, may not have been domestic but commissioned for the tomb alone, and thus closely connected with the funerary beliefs of the time. Furniture made of expensive materials, such as ivory, gold, and silver, has so far been found only in tombs in the northern part of the Greek world. Whether similar pieces of furniture decorated the domestic interiors of the upper classes can only be surmised, since no conclusive archaeological evidence has so far been discovered.

\section{FURNITURE IN TEMPLE INVENTORIES}

The richest epigraphical sources of evidence for furniture in antiquity are the inventories of treasures stored in Greek temples and sanctuaries. This body of material raises several important questions. What types of furniture are mentioned in the so-called treasure lists? Why would one choose to dedicate furniture in a sanctuary? Was the furniture actually used by the priests, and was this in fact one of the principal reasons for such a dedication (as in the case of modern Greek Orthodox churches, where the chairs, icons, and candle-holders used in the mass often bear the names of their dedicants)?

These questions are not easily answered, in part because of the abbreviated format and variable state of preservation of the inscriptions that record sacred inventories. Furniture is sometimes specifically mentioned as part of a dedication, but more often it simply appears in a series of entries cataloguing cult equipment kept in storage. The names of the dedicants are rarely recorded or preserved: in most cases, only the objects are listed. ${ }^{32}$ It is impossible to say whether or not all or part of the dedicated furniture was ever used in the sanctuary. I will return to this question below, when I discuss the purpose and significance of dedicated furniture in more detail.

The most important surviving temple inventories are those from the Athenian Acropolis, the Sanctuary of Artemis Brauronia at Brauron, the Athenian Asklepieion, and a number of different sanctuaries and other buildings on the island of Delos. ${ }^{33}$ Although these inscriptions provide a wealth of vocabulary for furniture and other household objects, there nevertheless remain substantial problems with their use. In the first place, most of the inventories are neither systematic nor complete: it is not clear how many objects remained, for one reason or another, unrecorded or uninscribed, and the processes by which older offerings were disposed of or melted down for reuse are not well understood. In the second place, the

32. In the case of the Athenian Asklepieion, Aleshire has to my mind successfully proven that the $\alpha \gamma \rho \alpha \varphi \alpha$ or uninscribed objects, as well as those for which only the first name of the dedicant is recorded, are dedications by Athenian citizens, not slaves or metics (Aleshire 1992). According to Aleshire, such $\alpha$ $\gamma \rho \alpha \varphi \alpha$ "simply show that the dedicants lacked either the means or the inclination to record their names" (p. 89). Girard, on the other hand, proposed that they indicate dedicants of lower class or illiterates $(1881$, p. 83$)$. One should not rule out the possibility that some of these dedications, especially the furniture, might have been commissioned by the temple authorities for their own use (a possibility discussed further below).

33. The fundamental studies are, for the Athenian Acropolis, Harris 1995 and Hamilton 2000, pp. 247-344; for the Athenian Asklepieion, Aleshire 1989; for Brauron, Linders 1972; for Delos, Hamilton 2000. 
location of the objects within the sanctuary can rarely be reconstructed with accuracy. ${ }^{34}$

The case of the Delian temple inventories is particularly problematic. For the period of Delian independence they fall into two large groups: the inventories from 314 B.c. to the end of the 3rd century, and those from the end of the 3 rd century to 166 в.C., when the Athenians seized the island..$^{35}$ Only six of the approximately 500 surviving inventories are complete, however, something that makes general conclusions very difficult to draw. ${ }^{36}$

In spite of the fragmentary nature of the surviving inscriptions, the objects recorded in the Delian inventories are more varied and more numerous than those found in the most closely comparable group of inventories, those from the Athenian Acropolis. One reason for this may be that, as Hamilton points out, "the Acropolis inventories involved only a portion of the Athenian dedications, those belonging to Athena or left with Athena for safe-keeping." 37

Close examination of the Delian inscriptions has revealed discrepancies such as missing items in successive inventories of the same treasures. These discrepancies have been discussed by a number of scholars, among them Tullia Linders, who concludes that "the list of offerings, which never gives more than a selection of the treasure (a selection that varies from inventory to inventory) is, as Jacques Tréheux has pointed out, a symbol more than a record that the bieropoioi had fulfilled their duties." ${ }^{38}$ Hamilton, on the other hand, explains the omissions and discrepancies as "inadvertent incompleteness," perhaps resulting from the temporary physical relocation of part of the treasure ${ }^{39}$ Both explanations are possible and because of the fragmentary nature of the evidence neither argument is conclusive. In spite of all these problems, however, the types of furniture recorded in the Delian inventories and the occasional references to dedicants are pieces of information that remain valuable in themselves, regardless of the larger interpretative difficulties.

The types of furniture stored in the sanctuaries of Athens, Delos, and Macedonia included chests and other containers, washbasins, thrones, bed-couches, stools, and tables. Based on the surviving epigraphical record, we can deduce that the most elaborate materials were used for thrones, bed-couches, and some types of containers. Exceptional objects in the Attic inventories include pillows (Artemis Brauronia and the Athenian Asklepieion) and curtains (hero shrine in the Athenian Agora). ${ }^{40}$ Exceptional objects mentioned only in the Delian inventories are a wooden model of a house (Apollo Treasure C) and an ivory model of a hut (Apollo Treasure D), which are clearly dedications; boxes used specifically for books (Andrians Treasure D); and possibly curtain equipment (Hieropoion/ Andrians Treasure BB). ${ }^{41}$

34. A few "directional" phrases are preserved in some of the inventories, among them numbered $\dot{\rho} v \mu_{0}$ and

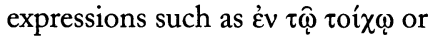

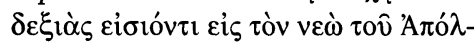
$\lambda \omega v o \varsigma$ (Tréheux 1955-1956, pp. 140141, 145-146; Moretti 1996; Prêtre 1999).

35. Linders 1988 , p. 38 . For a detailed conspectus of the Delian inventories, see Hamilton 2000.

36. Hamilton 2000, p. 1.

37. Hamilton 2000, p. 348.

38. Linders 1988, p. 41 (emphasis mine); Tréheux 1959, pp. 266-271.

39. Hamilton 2000, pp. 29-31.

40. Artemis Brauronia: Linders 1975, p. 75, n. 12; SEG XXXVII 34. Athenian Asklepieion: $I G \mathrm{II}^{2} 1533$ (= Aleshire 1989, inv. III), line 35.
Hero shrine in the Athenian Agora:

Rotroff 1978 (SEG XXVIII 53);

Lewis 1979 (SEG XXIX 146).

41. Building models: IDélos 399B, lines 37-38 (better preserved in 421, line 59); 1429AII, line 26; discussed further below, p. 580 and n. 150. Boxes for books: IDélos 1400, line 7. Curtain equipment: IDélos 320B, line 67. 


\section{THE VOCABULARY OF FURNITURE AND FURNISHINGS}

\section{Chests, Baskets, and Other Containers}

The vocabulary of containers in the epigraphical sources is particularly striking. ${ }^{42}$ The exceptionally rich vocabulary might suggest a rather specialized industry. One can deduce various shades of meaning in the case of some of these words, but no details concerning their shape or their covers. Materials and sizes are, however, often preserved. Few examples have been found in the archaeological record. ${ }^{43}$

Kavov̂v is a basket, used for ivories. ${ }^{44}$

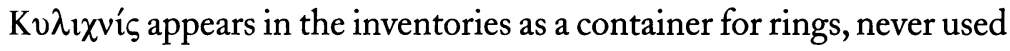
for other objects. ${ }^{45}$ Only once, in the Athenian Asklepieion, is it placed inside another case (an ह̌ $\lambda v \tau \rho o v) .{ }^{46}$

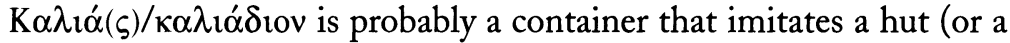
model of a hut). ${ }^{47}$

Koí $\tau$ is a case or tray. ${ }^{48}$ In the literary sources it is usually used for the transportation of food (including that sacrificed or dedicated to the gods). When referring to beds, however, the meaning is bedstead. The word kouri $\varsigma$ is probably not the diminutive of кoí $\tau$, as it is customarily translated, but rather a case or tray that resembles a koí $\eta .^{49}$

'A $\lambda \alpha \beta \alpha \sigma \tau 0 \theta \eta \dot{\kappa} \eta$ is a case for alabaster ornaments, perhaps of a special shape or material. ${ }^{50}$ 'E $\gamma \gamma v \theta \dot{\eta} \kappa \eta$ may possibly be a "stand for vessels and mixing bowls," as stated by Athenaios, who observes that those of the poor are made of wood and those of the rich of bronze or silver (Ath. 5.209f, 210c). ${ }^{51}$ In the epigraphical record it is attested only once,

42. For a comprehensive discussion of the literary sources, see Brümmer 1988. The English translations of Greek terms used here are based on the lexica (LSJ in particular); the work of Pritchett and Amyx on the Attic Stelai (Pritchett 1953, 1956; Amyx 1958); Prêtre 1997, for certain suffixes found in the Delian accounts in particular; and, finally, on the specific context of the inscription and the intended use of the object. In certain cases the use of one word in English to translate different words in Greek is unavoidable, since the meaning of some Greek terms is unknown and the vocabulary of containers in Greek is richer than that in English. One should also bear in mind that some Greek words might have been synonyms: the word $\sigma o p o ́ s$, for example, is glossed as $\theta \dot{\eta} \kappa \eta, \mu \vee \hat{\eta} \mu \alpha$,

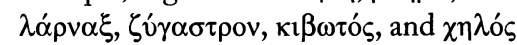
by Hesychios, Photios, and the Suda (Brümmer 1988, p. 15). Even if there was a difference in meaning in the 5 th and 4th centuries B.C., such nuances may have been lost by the time of the lexicographers. In any case, as Brümmer notes, "die einzelnen Ausdrücke bleiben nicht auf Unterschiede in der Form oder der Funktion, sondern-mit Ausnahme von Larnax - auf eine zeitliche oder lokale begrenzte Verwendung zurückgehen oder auch auf bestimmte Literaturgattungen beschränkt" (Brümmer 1988, p. 5). One can, however, detect slight differences in meaning in the suffixes used for certain groups of related nouns (e.g.,

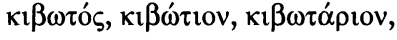
$\kappa \iota \beta \omega \tau i ́ \delta$ เov, discussed further below).

43. For representations of containers in Greek art, see Richter 1966, pp. 72-78; Brümmer 1988.

44. E.g., $I G \mathrm{II}^{2} 1378$, add. p. 797, line 13 (restored); 1399, lines 5-6 (restored); 1412, line 26; 1414, line 20; 1453 , lines 6-7 (restored).

45. E.g., $I G \mathrm{II}^{2} 1445$, line $45 ; 1448$, lines 2,$8 ; 1485$, lines 50-51; $I G \mathrm{I}^{3} 349$, line 57. According to Milne (1939), $\kappa v \lambda \iota \chi v i$ is was the Attic term for any small round box. In IDélos 298A, lines 108 and 110, however, it appears to be a miniature kylix.

46. IG II $^{2} 1533$ [= Aleshire 1989, inv. III], line 35.

47. $I G \mathrm{I}^{3} 292$, line 13.

48. E.g., $I G \mathrm{II}^{2} 1380$, line 5; 1408, lines 14-15; 1424a, line 142. The literary and visual evidence is discussed in Brümmer 1988, pp. 16-22. For the sale of a koit $\tau$ in the Attic Stelai, see Pritchett 1956, pp. 225-226. The sales tax was one obol and the restored sales price less than five drachmas.

49. E.g., IDélos $1444 \mathrm{Aa}$, line 35 ; 1450 , line 82 . For the meaning of the suffix, see Prêtre 1997, pp. 677678.

50. E.g., $I G \mathrm{II}^{2} 1408$, add. p. 799 , line 11; 1414, lines 24-25 (restored).

51. The testimony of Athenaios is dubious, since he simply presents us with a compilation of the earlier texts 
made of iron and gilded with bronze..$^{52} \Theta \dot{\eta} \kappa \eta$ is a more general term for a case; among the Delian examples is one of triangular shape containing the books of the poet Alkaios. ${ }^{53}$

"E $\lambda v \tau \rho o v$ is probably a case for easily breakable or expensive objects, since the items stored inside it include an ivory writing stick, a wooden lyre, a ritual knife, and a ball with a chain..$^{54}$

$\Pi \lambda \alpha i$ íov, in this context, is an oblong box without a lid, or a kind of tray with upright edges. In the inventories from Brauron, it frequently contains phialai or pieces of cloth. ${ }^{55}$ In the Delian accounts $\pi \lambda \alpha$ í⿴囗⿱一一) $\pi \lambda$ เv$\theta \varepsilon i$ ov are synonymous terms and often contain phialai. They might have been suspended from a wall or beneath a lintel..$^{56}$

Puzzling but extremely interesting are the words $\kappa \iota \beta \omega \tau$ ó $\varsigma, \kappa \iota \beta \omega ́ \tau \imath$,

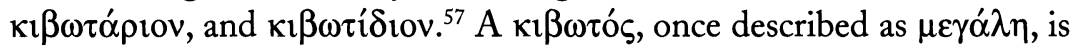
probably large: it should perhaps be translated as a "coffer," and is sometimes provided with a lid..$^{58}$ At least one example is made of papyrus. ${ }^{59}$

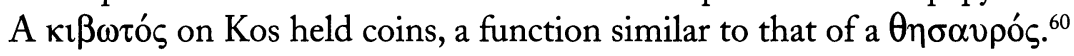
A кı

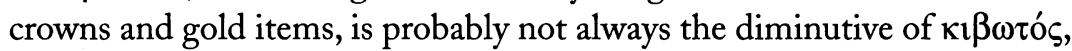
since one example is specifically designated $\mu$ เкpóv in a 5th-century inventory of Aphaia at Aigina. ${ }^{61}$ That it could be smaller than a кı $\beta \omega \tau$ ó $\varsigma$ is

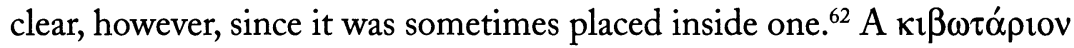
(diminutive? of $\kappa \iota \beta \omega \tau$ ó $\varsigma$ ) is attested only once and contained unweighed bronze objects. ${ }^{63}$

and lexica available in his patron's library. Until better evidence becomes available, however, the definitions he offers for obscure terms cannot be ignored.

52. IDélos 372B, line 30 (Delos Hieropoion/Andrians Treasure C).

53. IDélos 1400, line 7. For O彳́кп in the literary sources, see Brümmer 1988, pp. 15-16. For Alkaios, see Tréheux

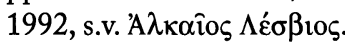

54. E.g., $I G \mathrm{II}^{2} 1424 \mathrm{a}$, lines 334$335 ; 1460$, lines 19-20; 1485, lines 52-53.

55. Linders 1972, p. 10. Such boxes are common in vase paintings where clothes are depicted folded or rolled into bundles. In the inventories of the Erechtheion a phiale is mentioned in a $\pi \lambda \alpha i \sigma ı v$ (Harris 1995, p. 213, no. VI.45). In the inventories of the Athenian Asklepieion $\pi \lambda \alpha i \sigma$ í $\alpha$ are mentioned twice $\left(I G \mathrm{II}^{2} 1534 \mathrm{~A}\right.$ [ = Aleshire 1989, inv. IV], lines 98-99).

56. For $\pi \lambda \alpha$ íotov and $\pi \lambda \iota v \theta \varepsilon i ̂ v$ in the Delian inventories, see Hellmann 1992. In other contexts the terms denote ceiling coffers.

57. For $\kappa \iota \beta \omega \tau o ́ \varsigma$ and $\kappa \iota \beta \omega ́ \tau \imath o v$ in the Attic Stelai, see Pritchett 1956, pp. 220-225. For further literary references on $\kappa \imath \beta \omega \tau$ ó , see Brümmer 1988, pp. 5-8 (especially p. 5, n. 5, for its synonyms). There is secure evidence for containers (possibly кı $\beta \omega ́ \tau \imath \alpha$

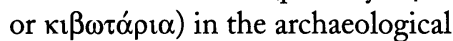
record: see, e.g., Siebert 1973 (Delos); Themelis 1979, p. 263 (Kallipolis, Aitolia); Themelis 1994 (Tomb of Philimina, Elis); Eretria X, p. 84, fig. 134 (House IV). A particular type of coffer recorded in the Attic Stelai

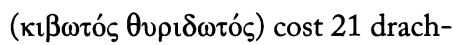
mas, the highest price paid for any piece of furniture. The price was presumably due to its decoration and size.

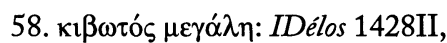
lines 52-53 (Apollo Treasure D).

59. IDélos 442B, line 214 (Artemision Treasure $\mathrm{C}$ ).

60. $L S C G$, no. 155 , line 13 (discussed further below).

61. IG $\mathrm{I}^{3}$ 1456, lines 10-11; SEG XXVIII 372. For the variable meaning of the suffix -tov, especially in the Delian inventories, see Prêtre 1997, pp. 673-677. According to Prêtre this suffix may indicate the group to which a noun belongs, the group that it resembles, or the noun of which it is a diminutive. Other ambiguous cases are also noted. The nuances are subtle and in the case of the containers in the Delian inscriptions no one secure translation is possible. The correct interpretation of forms such as $\kappa \iota \beta \dot{\omega}$ $\tau$ tov and $\kappa \iota \beta \omega \tau \alpha$ óptov should account for all three of the possibilities mentioned above (a container used like a кı $\beta \omega \tau$ ćs, a container that resembles

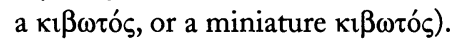
The meaning must be deduced case by case, and the objects stored in the containers are the best guide to translation.

62. IDélos 396B, line 73 (Artemision Treasure C). A кıß́์ lost its lid, or never had one, is listed in IDélos 1409BaII, line 39 (Andrians Treasure D).

63. IDélos 1417AI, lines 103-105:

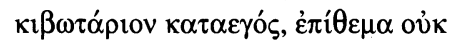

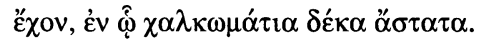

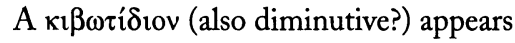
in $I G \mathrm{XI} 2147 \mathrm{~B}$, lines $10-11$. 
The fact that these terms for various sizes and types of containers are used more or less at random is demonstrated by a Delian inventory in

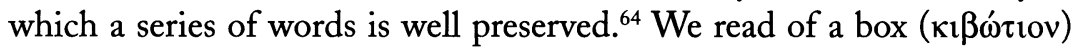
that contained reliefs and a ring, another box ( $\kappa$ i $\left.\beta \omega^{\prime} 10 v\right)$ that contained

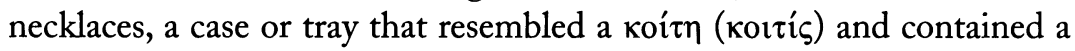
gold shield, and finally a coffer ( $\kappa \iota \omega \tau$ ó $\varsigma$ ) that contained silver items. It is

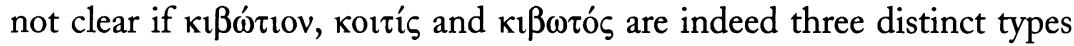
of container, or if the scribe used three synonyms to denote containers of similar size, material, decoration, construction, or value. I tend to believe that the latter is the case, in part because of the existence of inscriptions in which two words are used for what appears to be the same object. A good example is provided by IDélos 1400, line 7, and IDélos 1409BaII, line 39, where the phrase $\kappa \iota \omega \tau$ iò $\pi \alpha \lambda \alpha$ ió $v$ in the first inscription is replaced by $\kappa \iota \beta \omega ́ \tau ı v ~ \pi \alpha \lambda \alpha$ ióv in the second. Since both are records of the same treasure (Andrians Treasure D), and each entry occupies the same position within the sequence of listed items, there is no reason to doubt that both inscriptions refer to the same object. In this case the suffix - lov perhaps represents not a diminutive but a container that resembles a кı $\beta \omega \tau$ tós. The two scribes evidently had different perceptions of the object they recorded.

$\Lambda \alpha \rho \rho \alpha \xi$ is attested in these inscriptions only in the Delian inventories, where it is characterized as "old" ( $\pi \alpha \lambda \alpha i \alpha)$ or of an "archaic" style

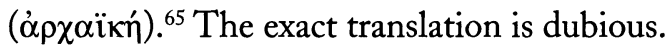

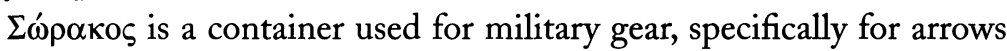
or shields. ${ }^{66}$

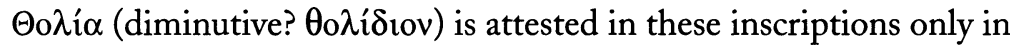
the inventories of the Athenian Asklepieion. ${ }^{67}$ In Pollux (10.138.6) the word means a chest with a conical lid.

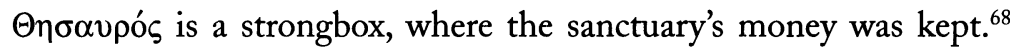

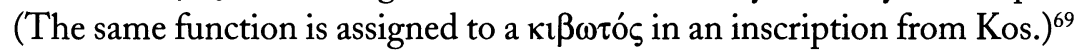
Excavated $\theta \eta \sigma \alpha v \rho o i ́$ are heavy stone monuments, usually provided with locks. An example with the word $\theta \eta \sigma \alpha v$ ós inscribed upon it was found in Athens, in its second use, during the demolition of a house. ${ }^{70} \mathrm{It}$ is dated on epigraphical grounds to the early 4th century B.C., and was used for the collection of a money donation ( $\dot{\alpha} \pi \alpha \rho \chi \eta)$ connected, in this case, with a

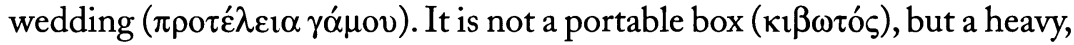
stone monument that weighs $1,472 \mathrm{~kg}$ and locks with a key. We might

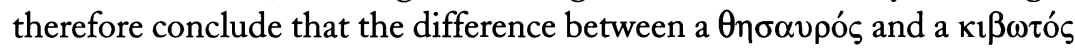
is chiefly one of size and weight.

64. IDélos 1444Aa, lines 34-37

(Artemision Treasure D).

65. IDélos 1409BaII, line 38 ( $\pi \alpha \lambda \alpha \alpha_{1}$ );

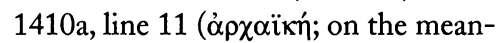
ing of this term, see Prêtre 1999, p. 395); $1449 \mathrm{~d}$, line 11 (no adjective preserved). For the term $\lambda \dot{\alpha} \rho v \alpha \xi$, see Brümmer 1988, pp. 12-14, esp. nn. 71-73 on the

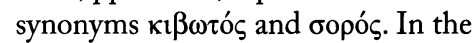
archaeological literature $\lambda \alpha \dot{\alpha} p v \alpha \xi$ is used to denote a funerary urn with a lid: see, e.g., Adams 1983 for the famous $\lambda \alpha$ ópv $\alpha \kappa \varepsilon \zeta$ found in the tumulus at Vergina.
66. E.g., IDélos 104/28bB, line 12; also attested in Aen. Tact. 30.2.3.

67. IG $\mathrm{II}^{2} 1533$ (= Aleshire 1989, inv. III), line 31; 1534B + 1535 (= Aleshire 1989, inv. V), line 155. For the meaning of the word, see Aleshire 1989 , p. 332.

68. E.g., IDélos 1417AII, line 142; 1443AI, lines 140, 148. The usual German translation is "Opferstock." For a comprehensive typological study of

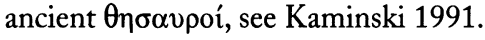

69. $L S C G$, no. 155 .
70. Tsakos 1990-1991; Kazamiakis 1990-1991. This complete, marble monument is similar to the money box of a modern Greek Orthodox church. Kazamiakis (p. 31) has estimated its capacity as 20,000 Athenian drachmas. I would like to thank S. Zoumbaki for bringing this study to my attention. Other excavated examples of Onoavpoí, of which only the upper or the lower part is preserved, are cited in Tsakos 1990-1991, p. 28, with reference to Kaminski 1991. 
The terms $\varphi \alpha ́ \sigma \kappa \omega \lambda$ ov and $\sigma \kappa \hat{\tau} \tau ం \varsigma$ refer to bags, which were also used as containers for smaller articles or musical instruments. A $\varphi \alpha ́ \sigma \kappa \omega \lambda$ ov containing a batch of small silver objects is recorded in the inventories of Artemis Brauronia. ${ }^{71}$ The word $\sigma \kappa \hat{v} \tau o \zeta$ is attested only once in the surviving inventory inscriptions. ${ }^{72}$ A related term, кo $\lambda$ cóv, denotes a sheath for knives. ${ }^{73}$

$\Phi \alpha ́ \tau v \eta$ is a problematic word. Originally used for an animal's manger, in this context it might denote a table, an oblong box with partitions, or a cupboard, if the restoration of the contents of a $\varphi \alpha$ q $\tau v \eta$ in $I G \mathrm{II}^{2} 1487$ is correct. $^{74}$

\section{Chairs and Footstools}

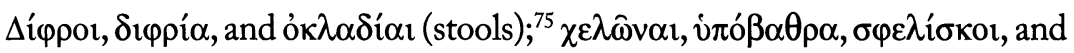

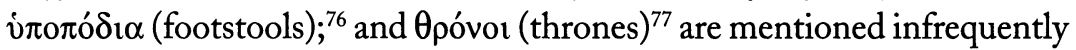
in the surviving inscriptions. 'Y $Y$ ó $\beta \alpha \theta \rho \alpha$ vvv $\varphi \iota \kappa \alpha$ are attested once and might refer to footstools used by brides. ${ }^{78}$ The small number of footstools in the archaeological record, from tombs in Macedonia and Eretria, limits any further discussion of their typology. ${ }^{79}$ Footstools are, however, often depicted on vase paintings and funerary stelai, accompanying thrones or beds. ${ }^{80}$ They might have been used for hygienic reasons, so that the feet of the seated persons would not touch the ground. ${ }^{81}$

\section{BED-COUChES AND TABLES}

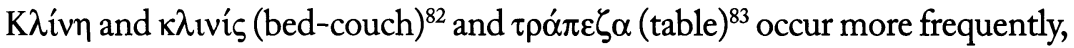
no doubt because of their association with sacred meals. We also have exceptional references to beds with tables that are pulled out from under them ( $\left(\dot{\pi} \delta^{\prime} \sigma \pi \alpha \sigma \tau \alpha \tau \rho \alpha \pi \dot{\varepsilon} \zeta(\alpha)\right.$, possibly to save space, and to an "unstretched bed"

71. IG $\mathrm{II}^{2} 1445$, line 22; 1453, lines 8-9.

72. IG $\mathrm{II}^{2} 1421$, line 120 .

73. $I G \mathrm{I}^{3} 342$, line 17.

74. $I G \mathrm{II}^{2}$ 1487, line 37: $\dot{\varepsilon}[v] \tau \hat{n}$

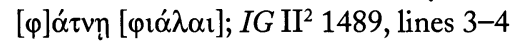
and 27 (both restored). For $\varphi \alpha ́ \alpha v \eta$ in the Attic Stelai, see Pritchett 1956, pp. 243-244. The price recorded in the Stelai is ten drachmas and one obol.

75. E.g., $I G \mathrm{I}^{3} 343$, line 14; II $^{2}$

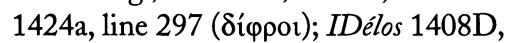
lines 11-12; 1417BII, line 77 ( $\delta 1 \varphi \rho i ́ \alpha)$; $I G \mathrm{II}^{2} 1379$, line 4 (óк $\lambda \alpha \delta i ́ \alpha \mathrm{l}$ ). For

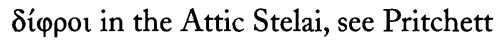
1956, pp. 215-217. The price listed in the Stelai is probably 1 drachma and 2 obols. One stool has been excavated in Greece, at a tomb in Stavroupolis near Thessaloniki: Andrianou 2006, p. 231.

76. E.g., IG XI 2 159, lines 26, 60; 199, line 67 ( $\chi \varepsilon \lambda \hat{\omega} v \alpha \mathrm{r}) ;$ IDélos 1412a, line 7 ( $\chi \varepsilon \lambda \omega v i ́ \varsigma) ; I G \mathrm{II}^{2} 1485$, line 54 (inó $\beta \alpha \theta \rho \alpha$ ); IG II 1533 (= Aleshire

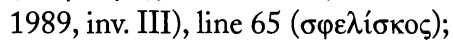

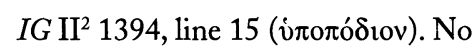
footstools are recorded in the Attic Stelai, possibly on account of their poor state of preservation.

77. E.g., $I G \mathrm{II}^{2} 1412$, line 3 (restored); 1438 , line 47; 1485 , line 43 . For Opóvor in the Attic Stelai, see Pritchett 1956, pp. 217-220. Neither price nor sales tax has been preserved for any of the thrones mentioned in the Stelai. For excavated funerary thrones in Vergina and Eretria, see Andrianou 2006, pp. 231-232. There are no excavated Classical or Hellenistic examples of thrones from domestic settings in Greece, including palaces. This, of course, does not preclude the existence of thrones made of perishable materials.

78. IG $\mathrm{II}^{2} 1485$, line 54 . For the socalled "bridal scenes" depicted on vase paintings, see Andrianou 2006, p. 222.

79. Andrianou 2006, p. 242.

80. Richter 1966, pp. 49-52.

81. I hope to discuss the archaeological and iconographical evidence for footstools in a future study.

82. E.g., $I G \mathrm{II}^{2} 1424 \mathrm{a}$, lines 341

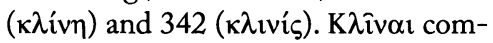
bined the roles of the modern bed and sofa, thus the most accurate translation is "bed-couch." For $\kappa \lambda \hat{i v} \alpha \mathrm{l}$ in the Attic Stelai, see Pritchett 1956, pp. 227-229. The average price of a "Milesian" bed in the Stelai is eight drachmas, that of a simple bed-couch six drachmas. For excavated parts of beds (mainly fulcra) from domestic contexts, and for the rich collection of surviving funerary beds, see Andrianou 2006, pp. 232-247.

83. E.g., $I G \mathrm{I}^{3} 343$, line 15; SEG XXXVII 35, from Brauron. For $\tau \rho \alpha ́ \pi \varepsilon-$ $\zeta \alpha \mathrm{l}$ in the Attic Stelai, see Pritchett 1956, pp. 241-243. The prices for tables in the Stelai range from 4 to 6 drachmas. A few tabletops and table legs have been found at Vergina, Eretria, Delos, and Pella (Andrianou 2006, p. 257). Two stone-built tables and a few benches are attested in funerary contexts (Andrianou 2006, p. 257). 


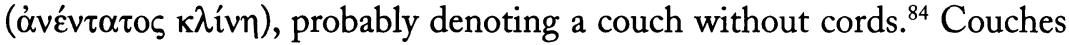

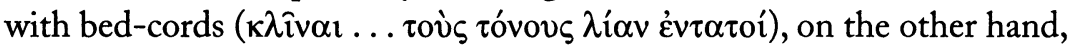
are mentioned at Eleusis. ${ }^{85}$ Sadly, no archaeological remains of bed-cords have survived.

The large number of bed-couches attested in the Delian inventories (102 in the Amphictyonic Group A and 60 in Chalkotheke Treasure B) is interesting. The records may denote parts of beds (legs, headrests) rather than fully assembled pieces of furniture.$^{86}$ If so, this may be an indication that wooden furniture was stored in pieces and put together only when needed for feasting.

Some bed-couches in the Athenian treasure lists are characterized as "Chian" or "Milesian," but the meaning of the adjective is not clear: does it indicate the ethnicity of the dedicants, the "artistic school" of the craftsmen, or the place of origin of the furniture itself or its materials? ${ }^{87}$ I am inclined to believe that the name denotes the region where a distinctive design or style of decoration was first "invented," although this cannot be proven, as Philippe Bruneau has discussed.$^{88}$ In a similar fashion, Pliny calls gold embroidery "Attalid" because it was "invented" in Asia by King Attalos (HN 8.196). "Delian" beds, on the other hand, are not explicitly mentioned in the epigraphical or literary record, contrary to the assumption of previous scholars. ${ }^{89}$

\section{TABLETS}

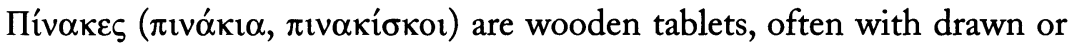
painted decoration..$^{90}$ Their significance and the meaning of the words used to describe them are disputed. They are discussed in detail below, pp. 579-581.

\section{WAS H B A S I N S}

Furniture for washing and food preparation is also attested epigraphically. ${ }^{91}$ Various types of washbasins and troughs, items that are less likely to be dedications, are mentioned in the inventories: $\chi \varepsilon \rho v \imath \beta \varepsilon i o v$ (hand basin),

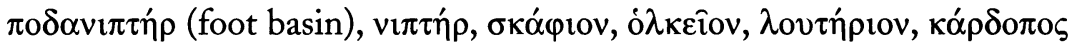

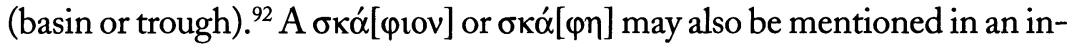

84. IDélos 1403BbII, lines 29-30, 33-34 (Kynthion Treasure D); 1416AI, line 38 (Sarapieion Treasure D).

85. IG $\mathrm{II}^{2} 1541$, lines 22-26 (partly restored).

86. IDélos 104, lines 143-144; 199B, line 90 . In each case the number of bed-couches is well preserved.

87. For references, see Andrianou 2006, p. 233, n. 74.

88. Bruneau 1976, pp. 27-36.

89. For discussion, see Andrianou 2006, p. 234.

90. E.g., IDélos 1412a, line 9; 1416AI, lines 38-39; 1442A, line 69. For $\pi i v \alpha \xi$ in the Delian inventories, see
Hellmann 1992, s.v. $\gamma \rho \alpha \varphi \eta$, and the discussion below. For $\pi i v \alpha \xi$ in the Attic Stelai, see Pritchett 1956, pp. 250-251. In the Stelai, an unknown number of

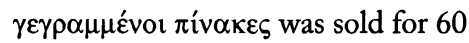
drachmas, a small $\gamma \varepsilon \gamma \rho \alpha \mu \mu \varepsilon ́ v o \varsigma$ for 6 drachmas and 4 obols.

91. For excavated washbasins from domestic complexes, see Cahill 2002, pp. 163-169 (Olynthos); Délos XVIII, pp. 78-80 (Delos); Blinkenberg 1898, p. 15 (Epidauros). For troughs, see Cahill 2002, p. 248; Délos XVIII, p. 81.

92. E.g., $I G \mathrm{II}^{2} 1445$, lines 24-25,

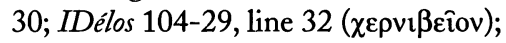

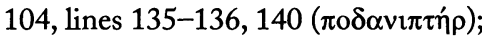

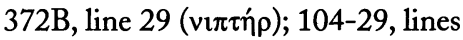

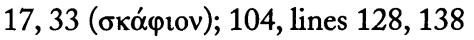

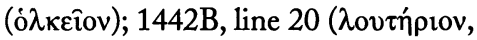

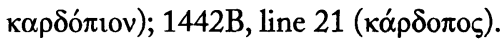
For $\chi \varepsilon \rho v i \beta \varepsilon i \alpha$ in the archaeological and literary record, see Ginouvès 1962 ,

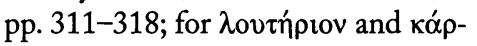

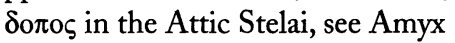
1958 , pp. 221-228, 239-241. The price

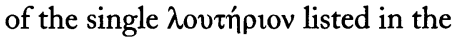
Stelai is not preserved; those recorded for the кó $\rho \delta$ o $\pi$ or vary from 7 drachmas and 2 obols for a stone example to 2 drachmas for one of clay. 
scription found in Macedonian Beroia and dated between 240 and 225 в.c., which lists silver vessels bought with sacred funds and deposited in a temple, possibly that of Asklepios. ${ }^{93}$ The vessels were purchased with the money earned from the selling of animals, which had been given to the shrine as $\theta \dot{\sigma} \sigma \mu \alpha$ (for sacrifice). ${ }^{94}$

\section{Rugs, Cushions, and Pillows}

An inventory from a hero shrine, dated after $328 / 7$ B.c., has been found in the Athenian Agora. ${ }^{95}$ The inscription, which is relatively well pre-

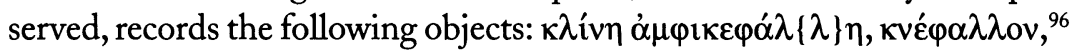

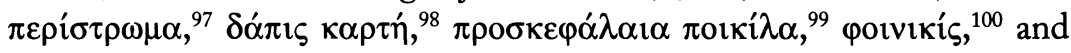
$\sigma \iota \mu \delta \omega \mu[\ldots],{ }^{101}$ as well as pottery dedicated by the Boule. ${ }^{102}$ The fact that furniture and furnishings such as beds, pillows, and even curtains are recorded among the contents of the shrine suggests that feasting of some kind probably took place as part of the hero's cult. Such furnishings, although rarely preserved in the archaeological record, are well attested in representations on red-figure pottery. ${ }^{103}$ Wall hangings would have served as partitions in rooms when needed, while cushions, covers, and pillows would have increased comfort.

\section{THE SIGNIFICANCE OF FURNITURE DEDICATIONS}

In the period covered by the present study, from the 4th to the 1st century B.C., there is no clear indication of the purpose of dedicated furniture. The dedicatory inscriptions preserved on some of the furniture found in sanctuaries are generally fragmentary and provide no information other than the name of the dedicant. For the majority of furniture listed in the temple inventories no names at all are recorded, a fact that might

93. Allamani-Souri 1990; Gounaropoulou and Hatzopoulos 1998 , pp. 119-121, no. 16 , line 9 (restored); $S E G \mathrm{XL} 530$. For the use of a $\sigma$ kó $\varphi$ iov in the context of a symposium, see Ath. 4.142d.

94. For a discussion of the term

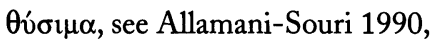
pp. 210-211. If the animals mentioned in this inscription were figurines of precious metal rather than actual livestock, they could perhaps have been melted down to be recast into new offerings (cf. Rouse [1902] 1975, p. 67, n. 2, for a similar interpretation of an offering at Delos). For the recasting of small votive objects in general, see Aleshire 1989 , p. 83; 1992, p. 98; Siewert 1996.

95. Agora inv. I 7475, found built into the foundations of a Late Roman building on the north side of the square: Rotroff 1978 (SEG XXVIII 53); Lewis 1979 (SEG XXIX 146).

96. A cushion or mattress. For אvé$\varphi \alpha \lambda \lambda o v$ in the Attic Stelai, see Pritchett 1956, pp. 247-248.

97. A bedcover (in the plural, carpets and room hangings). The word is not mentioned in the Attic Stelai.

98. $\Delta$ ó $\pi 1 \varsigma$ : a rug for the floor or the bed. Rotroff (1978, p. 199) notes that the adjective $\alpha \alpha \rho \tau$ ' ("shorn smooth") appears in the inventories from Brauron, where it is used of mantles; she translates the phrase $\delta \alpha \dot{\pi} \imath \varsigma \kappa \alpha \rho \tau \eta^{\prime}$ as a rug with little or no nap. For $\delta$ áлıs in the Attic Stelai, see Pritchett 1956, pp. 246-247.

99. Pillows. For $\pi \rho \circ \sigma \kappa \varepsilon \varphi \alpha ́ \lambda \alpha 10 v$ in the Attic Stelai, see Pritchett 1956, pp. 253-254. For pillows represented on stone funerary beds and the remains of a possible pillow in the Vergina tumulus, see Andrianou 2006, p. 249. 100. As Rotroff (1978, p. 199) points out, the most likely meaning here is "red curtain or carpet," although she notes that the word can also denote a Lakedaimonian, Macedonian, or Persian military cloak, and so might suggest a connection with one of these areas.

101. LSJ defines $\sigma ı v \delta \omega ́ v$ as a fine cloth, usually of linen. Rotroff (1978, p. 199) suggests a bedsheet or wall

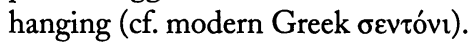

102. The inscription indicates that the Boule dedicated only the pottery, not the furniture.

103. For representations of furnishings on Greek vases, see Richter 1966, pp. 117-121. For evidence of furnishings in the archaeological record, see Andrianou 2006, pp. 249-250. 
suggest that not all were dedications in the first place. Bearing in mind the fragmentary state of most of the evidence and the provisional nature of any conclusions, I would like to examine three possible reasons for the presence of furniture in the sanctuaries: that it served as mobilier du culte, that it was used for safekeeping and storage, and that it was intended for display.

\section{Mobilier DU CULTE}

It is rarely possible to determine who dedicated a piece of furniture, or why such a dedication was preferred to other kinds of offerings. If we leave aside containers (which constitute the vast majority of recorded dedications), only a handful of examples of clearly votive furniture are preserved in the epigraphical record: a table offered by Hieron, a bed-couch by Pyrrhos, and a few $\pi$ iv $\alpha \kappa \varepsilon \varsigma$ dedicated chiefly by men, with the exception of one by a woman named Harpage. ${ }^{104}$ Little can be deduced from this evidence.

For most of the furniture mentioned in the temple inventories no dedicant is listed, and in such cases it is reasonable to ask whether some or all of it represented mobilier du culte. Here the incompleteness of the inscriptions and the practice of recording minimal information make it difficult to draw conclusions. The Athenian treasure lists, for instance, do not record the dedicants of any tables, chairs, or bed-couches, in part because of the poor preservation of the stones, but also apparently as a matter of convention. ${ }^{105}$

The role of the priests in obtaining cult paraphernalia might have been more significant than previously thought. The priests apparently paid attention to what was needed in the sanctuary and had three options: (1) to commission it themselves; (2) to recast old offerings that were beyond repair into new cult furniture; or (3) to ask their pious dedicants for appropriate dedications. There is evidence for all three of these activities:

1. The Delian inventories list two tables commissioned by the priests, presumably for the sanctuary's needs: one an oak

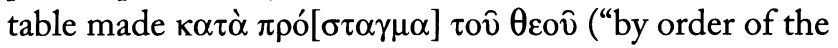
god"), the other a silver table and a caduceus [پ்] $\dot{\varepsilon} \varphi$ ' $\dot{\eta} \mu \hat{\omega} v$ к $\alpha \tau \varepsilon \sigma \kappa \varepsilon v \alpha ́ \sigma \theta \eta$ ("made by us [i.e., the priests]"). ${ }^{106}$

2. It seems to have been common in the Sanctuary of Artemis Brauronia in Athens to melt down votive offerings of gold or silver when they were beyond repair, and then to recast them into

104. IDélos 1428II, lines 48-50 (Apollo Treasure D); 1416AI, lines 19-20 (Sarapieion Treasure D); 1417AI, lines 76-77 (Thesmophorion Treasure D).

105. Harris (1995, p. 223) points out how infrequently the name of the dedicant is recorded in the Acropolis inventories.

106. IDélos 1428II, lines 48-50
(Apollo Treasure D); 199B, line 73

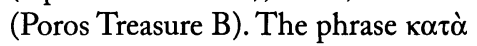

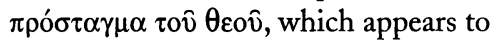
represent the command of the god (possibly in return for his services), might indicate the need for a table in the sanctuary. The second example was clearly made by the priests themselves. 
new cult furniture. ${ }^{107} \mathrm{~A}$ law of $335 / 4$ B.c. illustrating this procedure is mentioned by Linders, who observes that "the items, which are to be melted down, are small objects and

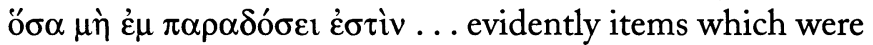
kept apart by the temple staff and therefore not among those formally handed over at the annual paradosis." 108

3. In an inscription from Beroia in Macedonia dated to 249/8 в.с., the priests of Herakles clearly ask for the dedication of skyphoi instead of phialai at the sanctuary. ${ }^{109}$

A sanctuary's furniture could be used for special celebrations or to serve everyday needs. In this respect the function of furniture in a sanctuary was similar to its function in a house: tables, bed-couches, bedcovers, wall hangings, and furniture for bathing all filled the same needs in both domestic and sacred contexts.

A series of passages in the Delian inventories yield information about one cult practice that required furniture, the so-called sacred meal. The texts concern two festivals, the Posideia and the Eileithyaia. ${ }^{110}$ The relevant passages are found in eight inscriptions dated to the first decades of the 2nd century в.c. and studied by Tullia Linders. ${ }^{111}$ They look like "shopping lists" for the feasts, which may have taken place outside the sanctuaries, since the space within the sacred area was limited. (Scholars have estimated that the number of participants in the Posideia might have been as great as $1,000.)^{112}$

Similar evidence can be found among the "sacred laws" regulating the property of sanctuaries in various parts of the Greek world. ${ }^{113} \mathrm{~A}$ 2nd-century

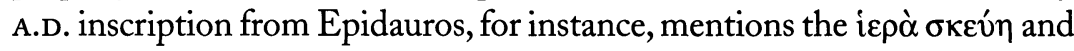
forbids anyone to use them privately or take them away. ${ }^{114} \mathrm{~A} 6$ th-century B.c. inscription from Argos forbids the use of the "sacred furniture" ( $\chi \rho \eta \sigma \tau \eta \dot{\eta} \rho 1 \alpha)$ outside the temple. ${ }^{115}$ A 2nd- or 1st-century B.c. inscription from Cyrene

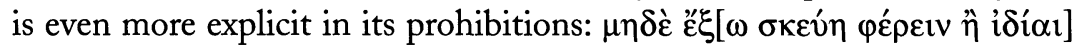

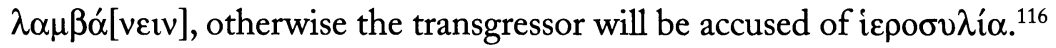

Tables from sanctuaries have received special treatment in the archaeological literature, since they have been found at a number of sites, and

107. Linders 1972 , p. 54 . Aleshire notes that the priests of the Athenian Asklepieion had the right to recast small offerings into a "larger and more impressive dedication labeled with the priest's name, his priestly titles and the

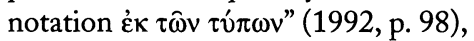
and that "this privilege apparently did not require the approval of the boule or demos" (1989, p. 83). See also Siewert 1996, for war offerings at Olympia that were recast into $\chi v \dot{\mu} \alpha \tau \alpha$; and IDélos $442 B$, lines $118-125$, for $\chi v ́ \mu \alpha \tau \alpha$ in 2nd-century Delos. I would like to thank S. Zoumbaki for bringing these examples to my attention.
108. Linders 1972 , p. 56 , on $I G \mathrm{II}^{2}$ 333 , line 27. During the $\pi \alpha \rho \alpha$ ó $0 \sigma 1 \varsigma$ the outgoing bieropoioi, whose duty it was to deliver the offerings to the sanctuary, personally inspected and handed over the offerings to their successors in the presence of the Boule. For certain discrepancies regarding this custom at Delos, see Linders 1988.

109. Gounaropoulou and Hatzopoulos 1998, pp. 91-95, no. 3, lines 1213 (with earlier bibliography). The inscription is the second letter by Demetrios II, son of Antigonos Gonatas, to Harpalos, an epistates. The passage in

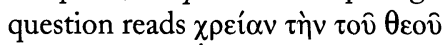

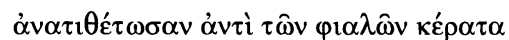

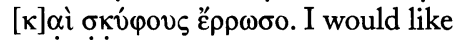
to thank E. Kosmetatou for locating the publication of this inscription for me.

110. Bruneau 1970, pp. 215-219, 260-264.

111. Linders 1991.

112. Linders 1991, p. 73.

113. Many of these are conveniently collected by Sokolowski (LSS, LSCG).

114. $L S S$, no. 24 , lines 3-4: $\mu \eta \delta \grave{\varepsilon}$

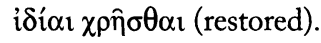

115. LSS, no. 27, lines 6-8.

116. LSS, no. 117 , line 8. 
some of them are inscribed. ${ }^{117}$ Most of the fragments come from Athens and Delos, a fact attributable to the large number of shrines excavated at those two sites. In certain sanctuaries tables were used for the placement of unburnt offerings for the god, a practice referred to in the inscriptions

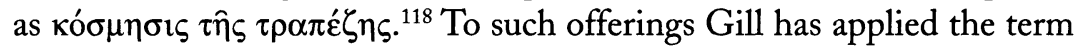
$\tau \rho \alpha \pi \varepsilon \zeta \dot{\omega} \mu \alpha \tau \alpha .^{119}$

The use of dining tables and bed-couches at sacrifices is recorded in a number of sacred laws: a decree of the Attic Orgeones dating to 306/5 в.c., for example, states that "when the Orgeones sacrifice to the hero in Boedromion, Diognetos is to provide the house where the shrine is, and have it open and roofed; and (he is to provide) a kitchen and bed-couches and tables arranged in two $\tau \rho$ ík $\lambda \iota v \alpha . " 120$ Ferguson, in his detailed study of

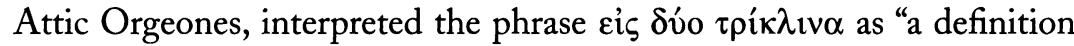
of capacity." 121 This inscription is important because it documents the transportation of cult furniture to the sanctuary when needed. Similarly, a sacred law from Kos, dated around 300 в.c., names Herakles as the guest of honor at a sacrifice and banquet, and orders $\sigma \tau \rho \omega \mu v \eta \dot{~ a n d ~} \alpha \gamma \alpha \dot{ } \alpha \mu \alpha \tau \alpha$ to be arranged at his statue. ${ }^{122}$

Bedcovers, pillows, and hangings were probably also used during meals. In the surviving inventories such textiles are regularly listed without a dedicant, and as in the case of the furniture itself, might represent either the dedications of male or female weavers or purchases made by temple authorities in order to furnish the temple interiors. They are not restricted to female deities: in addition to Artemis Brauronia, they are recorded among the possessions of male gods such as Asklepios and the hero or the eponymous heroes of an anonymous shrine in the Athenian Agora. ${ }^{123}$ In the latter case, the bedcovers might have been part of a state dedication. Another inscription from the Athenian Agora, dated to 191/0 в.c., preserves a decree passed in honor of a committee of three men appointed

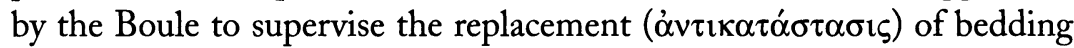
$(\sigma \tau \rho \omega ́ \mu \alpha \tau \alpha)$ in the Skias, and to inspect certain articles and make a list thereof. ${ }^{124}$ This is a clear indication of the practical use of $\sigma \tau \rho \omega \mu \alpha \tau \alpha$, the bedclothes and coverings of dinner-couches. A sacred law preserved in a decree of the Orgeones of Piraeus, dated around 183/2 B.c., mentions the

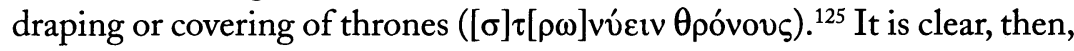
that textiles were used in sanctuaries to cover bed-couches, thrones, and, in one case, a $\pi$ ív $\alpha \xi$ (a portrait of Arsinoe[?] in the Kynthion on Delos). ${ }^{126}$

117. See Gill 1991 (with earlier bibliography). See also Petsas et al. 2000, pp. 76-78, for three table surfaces and four table supports, all inscribed, from the sanctuary at Leukopetra (Macedonia), and Misailidou-Despotidou 1997, p. 41 , no. 26 , for a 2 nd-century B.c. offering table from Pydna, inscribed with "Hellas."

118. E.g., $I G I^{2}$ 676, lines 14-15; 704, lines 14-15; 776, line 12.
119. Gill 1991, pp. 11-15, 20-23. For the verb $\tau \rho \alpha \pi \varepsilon \zeta o$ ' $\omega$ ("to place offerings on a table"), Gill (p. 12) cites $I G \mathrm{~V}$ 1 1390, line 86; IG V 1 3447; IG XII 2 72. From the 4 th century B.c. onward these offerings were received by the priest. The burnt sacrifices remained on the altar.

120. $L S C G$, no. 47 , lines 28-30; IG II $^{2} 2499$.

121. Ferguson 1944, p. 80, n. 27.
122. LSCG, no. 177, lines 95-97.

123. Brauron: Linders 1975 , p. 75 , n. 12; SEG XXXVII 34. Athenian Asklepieion: $I G \mathrm{II}^{2} 1533$ (= Aleshire 1989, inv. III), line 35. For the hero shrine in the Athenian Agora, see above, p. 567 and n. 40.

124. Thompson 1940 , pp. 144-145.

125. $L S C G$, no. 48A, lines 6-7.

126. IDélos 403a, line 8 (Kynthion Treasure D). 
Furniture for bathing was also popular. An example appears in the inscription that records the reform of the mystery cult at Andania in Mes-

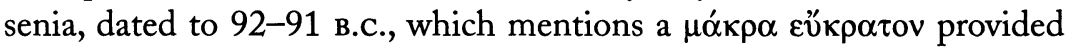

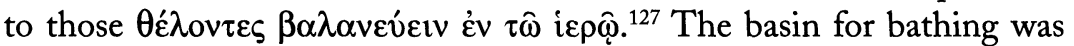

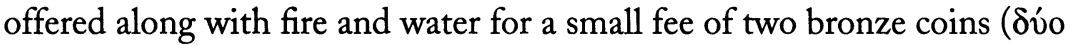

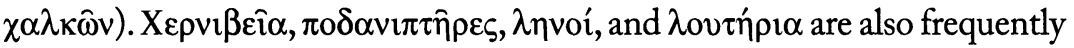
mentioned. ${ }^{128}$ Such vessels were customarily used during cult activities and feasting. ${ }^{129}$

An inscription of the late 5th century found in the Sanctuary of Artemis at Brauron, so far discussed only briefly in print, is important for the present study because it covers almost all of the groups of furniture discussed above. ${ }^{130}$ The full text of the inscription has not been published, but the list of items mentioned includes the following: $\kappa \lambda \hat{\imath} v \alpha \imath \mu \imath \lambda \varepsilon \sigma \iota \rho \gamma \varepsilon \varepsilon^{\prime}$,

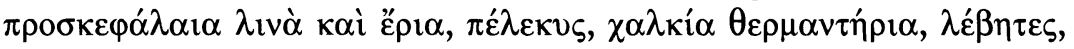

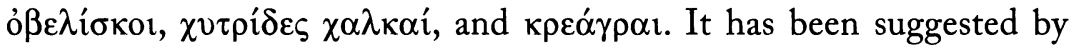
Petros Themelis that these are utensils for preparing, cooking, and serving food in a bestiatorion. ${ }^{131}$ The archaeological remains of furniture in the dining rooms associated with sanctuaries are limited to bed-couches and tables. ${ }^{132}$

If we return, then, to the question of whether the furniture found in sanctuaries was actually used, the answer is certainly positive. This is obviously true for those objects commissioned by the priests themselves. What remains open is whether the furniture in the treasure lists of Athens and Delos-the "true" votives for which the name of a dedicant is still preserved or was originally recorded-were dedications intended merely for display or whether they were also meant to be used. For this there is no clear evidence one way or the other, but the fact that votive dedications and simple lists of objects are recorded together might suggest that every piece of equipment was, or at least could have been, used at times.

\section{SAFEKEEPING AND STORAgE}

Sanctuary furniture also included various boxes for the safekeeping of money and other valuables. The dedication of boxes or objects in boxes was especially common on Delos.

127. LSCG, no. 65, line 107.

128. E.g., IDélos 104, line 127; 104-11B, line 28; 145B, line 60; 161B, lines 126-127; 372B, line 29.

129. Ginouvès 1962 , p. 79. For a depiction of a $\lambda$ ovtíptov at a symposium, see Avloniti 1999, p. 1252.

130. Linders 1975, p. 75, n. 12; SEG XXXVII 34.

131. Themelis 1986, p. 229. An inscription found at Chorsiai in Boiotia and dating to $386-380$ в.C. mentions klinai, tables, and utensils similar to those in the inscription from Brauron (Tomlinson 1980, pp. 221-224; SEG XXIV 361). It is associated with the hestiatorion of the Sanctuary of Hera.

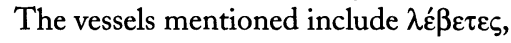

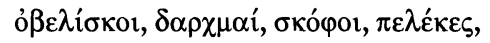

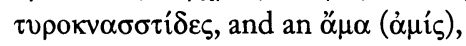
a portable urinal. The lampstands perhaps indicate dining at night, and

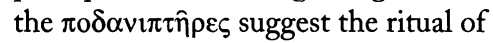
washing the feet before reclining. In the Roman period a praetorium used as a hotel and restaurant is mentioned in an exceptional inscription found at Dion (Pantermalis 2002, pp. 377-381). The text, inscribed on the surface of a table in its second use, lists a variety of furniture and furnishings: lecticubiculares, lecti tricliniares, culcitae, pulvini, subsellia, cathedrae, emitulia, and grabati.

132. For the setting of the ritual meal in Greek sanctuaries, see Goldstein 1978; the arrangement of the furniture and the furnishings is discussed on pp. 299-309. 
Some boxes were clearly made to meet a sanctuary's needs: a 3rdcentury inscription from Kos, for example, refers to the construction of

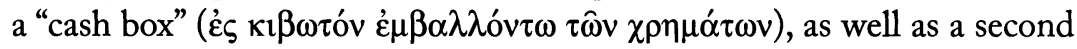

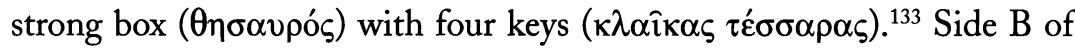
the same inscription refers to the same (or another) "collection box" next

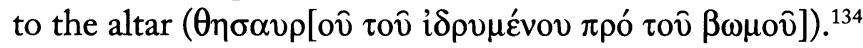

Containers in the Athenian treasure lists often hold other objects. The question is whether such containers were themselves dedications (when empty) or parts of dedications (when they contained other objects), or whether they were provided by the sanctuary in order to keep other dedications safe and in order. Were boxes employed to store single, possibly fragile, offerings? Were larger containers used to store offerings from different dedicants? Did organization matter? Were the names of the dedicants painted or engraved on the containers? It is not possible to answer such questions definitively, but a few examples from the inventories can illustrate the problems involved.

A rather complicated example appears among the recorded treasures of the Opisthodomos. ${ }^{135} \mathrm{~A}$ painted box was dedicated by Kleito, daughter of Aristokrates, wife of Kimon. Inside the box was a $\kappa v \lambda \iota \chi v i \varsigma$ (restored in the inscription), and inside the $\kappa v \lambda \iota \chi v i \varsigma_{\zeta}$ a gold ring with a sealstone, dedicated by Dexilla. In this case we have a reference to two boxes, a gold ring, and the names of two dedicants. More jewelry and pieces of clothing (o $\chi \theta 0$ or $\beta$ s) are mentioned thereafter in the inscription. It is not clear what belonged to Kleito's dedication and what belonged to that of Dexilla. ${ }^{136}$ The placement of the two containers, one inside the other, might suggest that the temple authorities combined two gifts into one, either because of lack of space or because the dedicants were related and dedicated the objects at the same time. If the reason for the combination of gifts was lack of space, it might explain why the name of only one of the two dedicants was recorded on the box.

Similar is the case of Thaumarete, wife of Timonides, who is recorded to have dedicated an ivory lyre and plectrum in a box. ${ }^{137}$ From the inscription it is not clear whether she dedicated the box as well as the musical instrument stored inside it.

Some boxes might indeed have been provided by the priests: a gold wreath ( $\sigma \tau \varepsilon \dot{\varphi} \varphi \alpha v \circ \varsigma \chi \rho v \sigma o \hat{\varsigma} \varsigma$ ) is recorded in the Acropolis inventories from $429 / 8$ в.C. until $411 / 0$ в.c. without any reference to a storage container, but

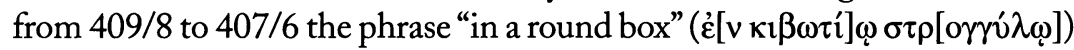
is added to the listing. ${ }^{138}$ If the wreath itself is the same throughout, then it

133. $L S C G$, no. 155 , lines A 13 , 15. Cf. $L S C G$, no. 65 , lines $91-94$, for similar provisions.

134. LSCG, no. 155 , line B 4. The interpretation of this inscription has been debated. Herzog (1903, p. 190), the excavator of the sacred area of

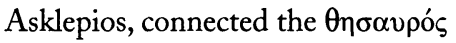
with a sacred pit found in Temple B. Meaningful objections to this interpretation have been raised by Kaminski
(1991, pp. 133-146), who envisions the

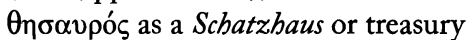
building located south of Temple B.

She believes that both sides of the inscription refer to the same $\theta \eta \sigma \alpha v$ pós. 135. IG $\mathrm{II}^{2} 1388$, lines 81-82;

Harris 1995 , p. 51 , no. II.37.

136. Hamilton (1996) notes a discrepancy in $I G \mathrm{II}^{2} 1447$ and 1451, where Kleito is associated with a different item (the ivory lyre and plectrum discussed below: Harris 1995, p. 57 , no. II.71).

137. $I G \mathrm{II}^{2} 1388$, add. p. 798, lines 79-80; Harris 1995, p. 57, no. II.71.

138. E.g., $I G \mathrm{I}^{3} 297$, lines $22-23$ (without mention of the storage place); $I G \mathrm{I}^{3} 314$, lines 8-9 (with mention of the storage place). Harris 1995 , p. 77 , no. III.41. 
seems likely that the box was provided much later by the sanctuary rather than by the original dedicant (unless the earlier inventories have simply omitted it). It is possible that the priests recognized the fragility of the dedication and took care for its proper storage. If this assumption is valid, the role of the keepers of the treasures was an important one, since they were not only recording the objects but actively caring for their preservation, keeping them properly in order and in good condition.

For the same reasons, a table rather than a box might have been provided by the keepers of the shrine of Asklepios in Piraeus, the contents of which are recorded in an inscription of the early 4 th century B.c. ${ }^{139}$ After a

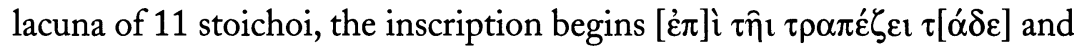
then lists a number of objects, including various sorts of drinking vessels

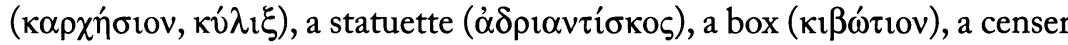

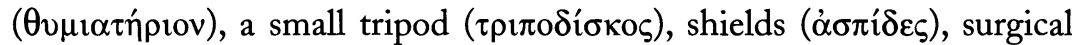

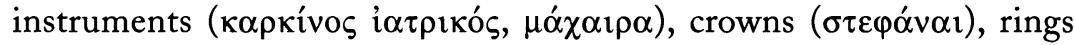

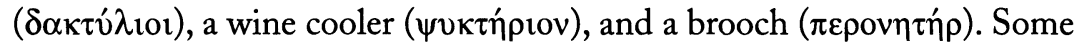
objects are described as chained ( $\dot{\alpha} \lambda \hat{v} \sigma \varepsilon \imath \delta \varepsilon \delta \varepsilon \mu \varepsilon ́ v o \varsigma)$, presumably to the table itself: a $\sigma \iota \kappa \dot{\alpha} \alpha$ (a fruit or a cupping-glass?), two $\sigma \tau \lambda \varepsilon \gamma \gamma i ́ \delta \varepsilon \varsigma$ (scrapers), and

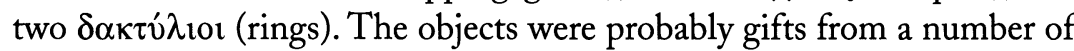
different dedicants. Some were chained because of their value, or perhaps because of their shape, so as to keep them safely on the table. Although the inscription does not give any information about the table itself, the possibility remains that it was commissioned by the sanctuary rather than dedicated by a pious yet unnamed worshipper.

\section{DISPLAY}

Certain pieces of furniture mentioned in the treasure lists were clearly

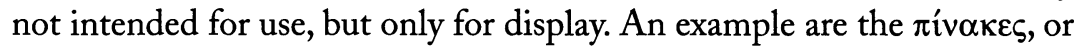
painted tablets, that constitute an exceptional category of furnishings in the Delian inventories.

The terms used for $\pi$ ívoke $\zeta$ were studied in a very preliminary form by René Vallois, and more recently by Marie-Christine Hellmann. ${ }^{140}$ The

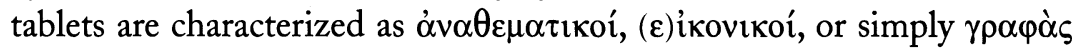
"z $\chi 0 v \tau \alpha \varsigma$. One is specifically recorded as having a $\chi \varepsilon i \rho o \gamma \rho \alpha \varphi i^{\prime} \alpha .{ }^{141}$ Vallois interpreted $\pi$ ív $\alpha \kappa \varepsilon \varsigma \dot{\alpha} v \alpha \theta \varepsilon \mu \alpha \tau \iota \kappa o i ́$ as paintings of religious inspiration

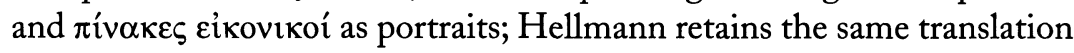

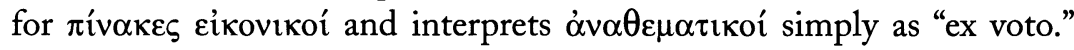
There is no doubt that the cikovikoi had some kind of picture on them, perhaps even of a relatively large size (an indication of megalographia?). The $\alpha \dot{\alpha} \alpha \theta \varepsilon \mu \alpha \tau \imath \kappa o i ́$ are more difficult to reconstruct with certainty, but since some were taken back to Rome by Aemilius Paullus and displayed during his triumph (Diod. Sic. 31.8.11), they must have been of some value. When both types are recorded in the inventories, the عiкovıкoi are always mentioned first, followed by the $\alpha \dot{v} \alpha \theta \varepsilon \mu \alpha \tau$ เ

139. $I G \mathrm{II}^{2} 47$.

140. Vallois 1913; Hellmann 1992, s.v. $\gamma \rho \alpha \varphi$ ń, esp. p. 93.

141. IDélos 1403BbII, lines 31-32, dedicated by Teleson, son of Autokles. sanctuaries, $\dot{\alpha} v \alpha \theta \varepsilon \mu \alpha \tau \iota \kappa o i ́$ are particularly numerous in the Gymnasium and the Heraion. The Kynthion had only вiкovıкoí.

Both types of $\pi$ ívokes were detachable, and most of them must have been small in scale. In the inventories some are characterized by the

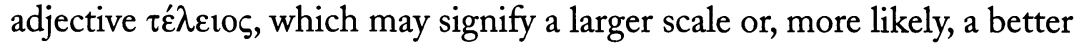


state of preservation. ${ }^{142}$ Some examples are described as $\tau \varepsilon \theta 0 \rho \omega \mu \varepsilon ́ v o r$ (with shutters), others as $\dot{\alpha} \theta \dot{p} \rho \omega \tau o r$ (without shutters), and one of the portraits(?) of Arsinoe was covered by a curtain $\left(\pi \alpha \rho \alpha \pi \varepsilon \tau^{\prime} \alpha \sigma \mu \alpha\right)$, possibly for protection. ${ }^{143}$ Still others are characterized as $\varepsilon^{\prime} \mu \beta \lambda \eta \tau o$, a word of uncertain meaning in this context. ${ }^{144}$ The $\pi$ ív $\alpha \kappa \varepsilon \varsigma \gamma \rho \alpha \varphi \grave{\alpha} \varsigma$ है $\chi 0 v \tau \alpha \varsigma$ might have been inscribed with a dedication, rather than bearing drawings or paintings (the equivalent of $\gamma \varepsilon \gamma \rho \alpha \mu \mu \varepsilon^{\prime} v o r$ in the Attic Stelai). ${ }^{145}$

Of all the Delian sanctuaries, the Aphrodision contained the largest number of dedicated $\pi$ ív $\alpha \kappa \varepsilon \varsigma .{ }^{146}$ This might indicate that pictures, perhaps depicting the goddess herself, were a common offering to Aphrodite. It is worth noting, however, that there is no indication of the subjects depicted on the figured $\pi i v \alpha \kappa \varepsilon \varsigma$, with the possible exception of a $\pi i v \alpha \xi$ of a priestess

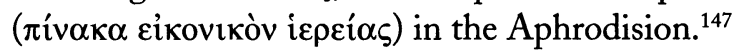

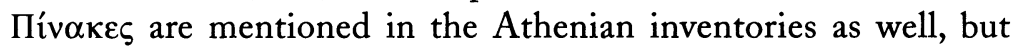
there is no evidence to indicate whether they were figured or not. ${ }^{148}$ The

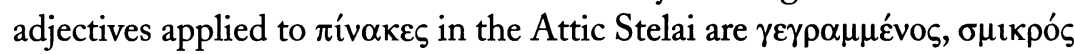

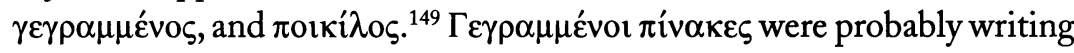

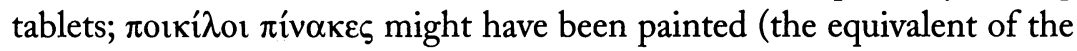
Delian عíkovıкоí).

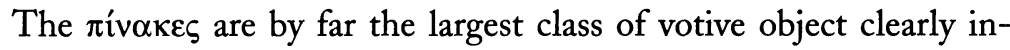
tended for display, but two other exceptional objects listed in the Delian inventories evidently had a similar purpose: a model of a house in Apollo Treasure C and a model of a hut in Apollo Treasure D. ${ }^{150}$ There is a striking lack of such models in the archaeological record of Classical and Hellenistic Greece, with one exception: a marble building model from Neapolis (modern Kavala), found during the excavation of the Sanctuary of Parthenos and dated to the 5 th century B.c. ${ }^{151}$ It has been interpreted as a votive sanctuary model. The "floor" of the model is missing (probably broken), and it was assumed by Welter to have been used as a money box. ${ }^{152}$ However, money boxes in the form of houses or sanctuaries are so far unknown from other Greek sites, and such a hypothesis is inconsistent with the weight and size of the Onoavpoí known from other excavations

142. Vallois (1913, p. 296) translates the term as "larger"; Hamilton (2000, pp. 220-221, Kynthion Treasure D, object no. 12, n. 129) as "complete" or "full-sized"; and Hellmann as of "grander nature" (1992, p. 93, s.v. $\gamma \rho \alpha \varphi \eta ́)$.

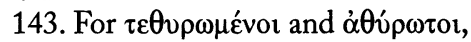
see the discussion in Hellman 1992, pp. 91-93, s.v. $\gamma \rho \alpha \varphi \eta$ (with references). $\pi \alpha \rho \alpha \pi \varepsilon ́ \tau \alpha \sigma \mu \alpha$ : IDélos 403a, line 8.

144. The term denotes "embossed" tablets, according to Hamilton (2000, p. 210, Artemision on Island Treasure D, object no. 94); pictures placed in a frame and set into the wall, according to Hellmann (1992, p. 124, s.v. ع̋ $\mu$ $\beta \lambda \eta \mu \alpha)$; or mosaics, according to
Orlandos (Orlandos and Travlos 1986, s.v. है $\mu \beta \lambda \eta \mu \alpha)$. Hellmann's interpretation seems the most likely.

145 . Hamilton (2000, p. 84, Athenian Treasure D, object no. 40) translates "with picture." For $\pi$ ív $\alpha \kappa \varepsilon \varsigma$ in the Attic Stelai, see Pritchett 1956, pp. 250-253; for $\gamma \varepsilon \gamma \rho \alpha \mu \mu \varepsilon ́ v o r$ in particular, pp. 251-252.

146. IDélos 1412a, lines 31, 33; 1414aII, lines 11-12; 1442B, line 32; 1443BII, line 101.

147. IDélos 1443BII, line 101.

148. $I G \mathrm{II}^{2}$ 1421, line 73: $\tau \hat{\omega} v$ $\pi \mathrm{\imath} \alpha \dot{\kappa} \kappa \omega \nu[\pi \varepsilon \rho \imath \mu \eta \dot{\eta} \mu \alpha \tau \alpha] ; I G \mathrm{II}^{2} 1474$, line 14: [ $\left.\pi^{\prime} i v\right] \alpha \xi \dot{\alpha} \rho \gamma v \rho o v[s] \dot{\varepsilon}[\varphi \hat{\varphi}] \dot{\varepsilon} \pi \mathrm{r}-$

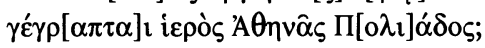
$I G \mathrm{II}^{2} 1438$, lines 40-41: $\pi \mathrm{i} v \alpha[\kappa \varepsilon \varsigma]$.
149. $I G \mathrm{I}^{3} 427$, lines 59-62; cf. Pritchett 1953, p. 282, for the restora-

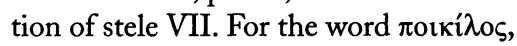
see Wace 1948 ; it may mean "decorated," "patterned," "of varied colors," or "simply painted."

150. IDélos 399B, lines 37-38 (better preserved in 421 , line 59 , with silver figurines inside); 1429AII, lines 26-27 (dedicated by Hanno of Carthage).

151. Bakalakis 1937 , p. 28 , no. 16 , fig. 38; Schattner 2001, pp. 201-202. Dimensions: L. 0.49, W. 0.25-0.27, H. $0.24 \mathrm{~m}$. I would like to thank Richard Hamilton for bringing Schattner's study to my attention.

152. Bakalakis 1937, p. 28, n. 1. 
(cf. above, p. 570). The house model in Apollo Treasure C on Delos was, in any case, not used as a money box, since according to the inscription it housed two silver animals.

\section{CONCLUSIONS}

It may be useful to think of an ancient Greek sanctuary as an echo of a "luxuriously" furnished contemporary home, in the same way that a modern, lavishly decorated church may allude to modern domestic interiors. From the body of evidence presented in this study, it appears that two types of furniture were commonly present in sanctuaries: those associated with storage (boxes, cupboards, shelves), and those associated with comfort (tables, chairs, beds). These are also the most decorated types of furniture found in funerary contexts, although relatively few examples have been preserved. ${ }^{153}$ Whether this was the case in domestic contexts as well, we are unable to tell at present, since the archaeological evidence from carefully excavated houses is so limited that we can draw few conclusions about the quantity and quality of furniture used in everyday life. The fact that in ancient loans and mortgages the house-gear was not transacted separately may indicate its small overall value.

It remains difficult given the current state of research to match the ancient terms for the various types of furniture (especially containers) with the depictions on pottery, for two main reasons: vase paintings themselves are not a safe indicator, since they cannot be treated as snapshots of daily life; and the vocabulary of furniture types is not yet fully understood. As a result we are left with a limited body of reliable evidence from archaeological, literary, and epigraphical sources with which to answer some of the many questions raised by modern researchers. In this study, and in its companion piece on the material recovered from excavations, I have collected and discussed some of that evidence. Future archaeological work in

153. See Andrianou 2006 for a discussion of the furniture found in tombs. the field of furniture and furnishings will no doubt lead us to reexamine our arguments and conclusions and bring us new insights into everyday life in ancient Greece. 


\section{REFERENCES}

Adams, J. P. 1983. "The Larnakes from Tomb II at Vergina," ArchNews 12, pp. 1-7.

Agora XIX = G. V. Lalonde, M. K. Langdon, and M. B. Walbank, Inscriptions: Horoi, Poletai Records, and Leases of Public Lands (Agora XIX), Princeton 1991.

Aleshire, S. 1989. The Athenian Asklepieion: The People, Their Dedications, and the Inventories, Amsterdam. - 1992. "The Economics of Dedication at the Athenian Asklepieion," in Economics of Cult in the Ancient Greek World. Proceedings of the Uppsala Symposium 1990 (Boreas 21), ed. T. Linders and B. Alroth, Uppsala, pp. 85-99.

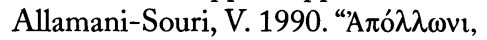

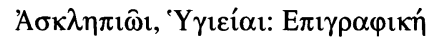

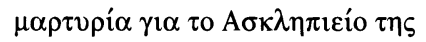
Bépotas," ArchDelt 39, A' (1984), pp. 205-231.

Amyx, D. A. 1958. "The Attic Stelai, Part III," Hesperia 27, pp. 163-310.

Andrianou, D. 2003. "'E $\pi \mathrm{\imath} \pi \lambda \alpha$ : Reconstructing Furnished Interiors in Hellenistic Greece" (diss. Bryn Mawr College). 2006. "Chairs, Beds, and Tables: Evidence for Furnished Interiors in Hellenistic Greece," Hesperia 75, pp. 219-266.

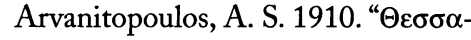

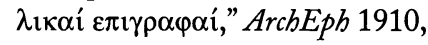
pp. 331-382.

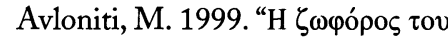

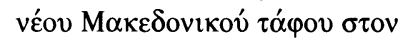

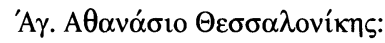
Eıкоvо Ancient Macedonia VI. Papers Read at the Sixth International Symposium Held in Thessaloniki, October 15-19, 1996, pp. 1247-1259.

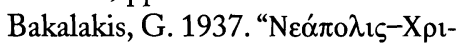

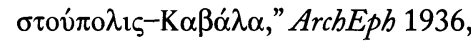
pp. 1-48.

Blinkenberg, C. S. 1898. "Epidaurische Weihgeschenke,” AM 23, pp. 1-23.

Brixhe, C., and A. Panayotou. 1994. "Le Macédonien," in Langues indo-européennees, ed. F. Bader, Paris, pp. 206-220.

Brümmer, E. 1988. "Griechische Truhenbehälter," JdI 100, pp. 1-168.
Bruneau, P. 1970. Recherches sur les cultes de Délos à l'époche hellénistique et à l'époche impériale (BEFFAR 217), Paris.

_. 1976. "D'un Lacedaemonius orbis à l'aes Deliacum," in Récueil Plassart: Études sur l'antiquité grecque offertes à André Plassart par ses collègues de la Sorbonne, Paris, pp. 15-45.

Cahill, N. D. 2002. Household and City Organization at Olynthus, New Haven.

Délos XVIII = W. Déonna, Le mobilier délien (Délos XVIII), Paris 1938.

Dubois, L. 1995. “Une tablette de malédiction de Pella: S'agit-il du premier texte macédonien?" RÉG 108, pp. 190-197.

Eretria $\mathrm{X}=\mathrm{K}$. Reber, Die klassischen und hellenistischen Wohnbäuser im Westquartier (Eretria: Ausgrabungen und Forschungen X), Lausanne 1998.

Ferguson, W. S. 1944. "The Attic Orgeones," HThR 37, pp. 61-174.

Fine, J. V. A. 1951. Horoi: Studies in Mortgage, Real Security, and Land Tenure in Ancient Athens (Hesperia Suppl. 9), Princeton.

Finley, M. I. 1952. Studies in Land and Credit in Ancient Athens, 500 200 B.C.: The Horos Inscriptions, New Brunswick, N.J.

Gauthier, P. 1976. Un commentaire historique des "Poroi" de Xénophon, Paris.

Gill, D. 1991. Greek Cult Tables, New York.

Ginouvès, R. 1962. Balaneutikè: Recherches sur le bain dans l'antiquité grecque (BÉFAR 200), Paris.

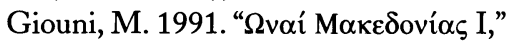

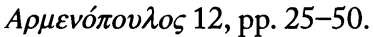

Girard, P. 1881. L'Asclépieion d'Athènes d'après de récentes découvertes (BÉFAR 23), Paris.

Goldstein, M. 1978. “The Setting of the Ritual Meal in Greek Sanctuaries, 600-300 в.c." (diss. Univ. of California, Berkeley).

Gounaropoulou, L., and M. B. Hatzo-

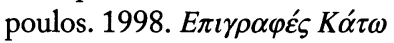

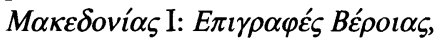
Athens.

Hamilton, R. 1996. Rev. of Harris 1995, in $B M C R$ 96.9.27. 
2000. Treasure Map: A Guide to the Delian Inventories, Ann Arbor.

Harris, E. M. 1988. "When Is a Sale Not a Sale? The Riddle of Athenian Terminology for Real Security Revisited," CQ 38, pp. 351-381.

Harris, D. 1995. The Treasures of the Parthenon and Erechtheion, Oxford.

Hatzopoulos, M. B. 1988. Actes de vente

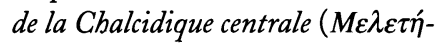
$\mu \alpha \tau \alpha$ 6), Athens.

Hellmann, M.-C. 1992. Recherches sur le vocabulaire de l'architecture grecque, d'après les inscriptions de Délos (BEFFAR 278), Athens.

Hennig, D. 1987. “Kaufverträge über Häuser und Ländereien aus der Chalkidike und Amphipolis," Chiron 17, pp. 143-169.

Herzog, R. 1903. "Vorläufiger Bericht über die Koische Expedition im Jahre 1903," AA 1903, pp. 186-199.

Kaminski, G. 1991. “Thesauros: Untersuchungen zum antiken Opferstock," JdI 106, pp. 63-181.

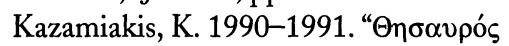

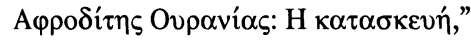
Horos 8-9, pp. 29-44.

Kent, J. H. 1948. “The Temple Estates of Delos, Rheneia, and Mykonos," Hesperia 17, pp. 243-338.

Lewis, D. M. 1966. "After the Profanation of the Mysteries," in Ancient Society and Institutions: Studies Presented to Victor Ehrenberg on His 75th Birthday, ed. E. Badian, Oxford, pp. 177-191.

- 1979. "An Inventory in the Agora," ZPE 36, pp. 131-134.

Linders, T. 1972. Studies of the Treasure Records of Artemis Brauronia Found in Athens $\left(S k r A t h 4^{\circ}, 19\right)$, Stockholm.

-1975. The Treasurers of the Other Gods in Athens and Their Functions (Beiträge zur klassischen Pbilologie 62), Meisenheim am Glan. . 1988. "The Purpose of Inventories: A Close Reading of Delian Inventories of the Independence," in Comptes et inventaires dans la cité grecque. Actes du colloque international d'épigraphie tenu à Neuchâtel du 23 au 26 septembre 1986 en l'bonneur de Jacques Trébeux, ed. D. Knoepfler and N. Quellet, Neuchâtel, pp. 3747.
1991. "Sacred Menus on

Delos," in Ancient Greek Cult

Practice from the Epigraphical

Evidence. Proceedings of the Second

International Seminar on Ancient

Greek Cult, Organized by the Swedish

Institute at Athens, 22-24 November 1991 (SkrAth 8 , 13), ed. R. Hägg,

Stockholm, pp. 71-91.

Milne, M. J. 1939. "Kylichnis," AJA 43, pp. 247-254.

Misailidou-Despotidou, V. 1997.

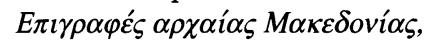

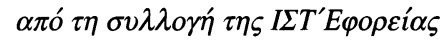

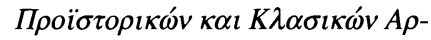
$\chi \alpha \imath \tau \tilde{\eta} \tau \omega v, K \alpha \tau \alpha \dot{\lambda} \lambda o \gamma o{ }^{\prime}{ }^{\prime} \kappa \theta \varepsilon \sigma \eta \varsigma$, Thessaloniki.

Moretti, J.-C. 1996. "Le gymnase de Délos," BCH 120, pp. 617-638.

Olynthus II = D. M. Robinson, Arcbitecture and Sculpture: Houses and Other Buildings (Olynthus II), Baltimore 1930.

Orlandos, A. K., and I. N. Travlos.

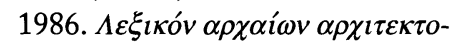
vıкஸ́v ó $\rho \omega v$, Athens.

Pantermalis, D. 2002. “Díov 2000,"

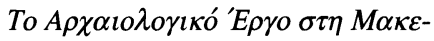

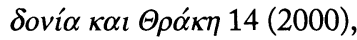
pp. 377-384.

Petsas, P. M., M. B. Hatzopoulos, L. Gounaropoulou, and P. Paschidis. 2000. Inscriptions du sanctuaire de la Mère des dieux autochthone de Leuko-

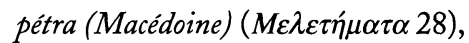
Athens.

Prêtre, C. 1997. "Imitation et miniature: Étude de quelques suffixes dans le vocabulaire délien de la parure," BCH 121, pp. 673-680. . 1999. "Le matériel votif à Délos: Exposition et conservation,” BCH 123, pp. 389-396.

Pritchett, W. K. 1953. "The Attic Stelai, Part I," Hesperia 22, pp. 225299.

- 1956. "The Attic Stelai, Part II," Hesperia 25, pp. 178-317.

Richter, G. M. A. 1966. The Furniture of the Greeks, Etruscans, and Romans, New York.

Robinson, D. M. 1928. "A Deed of Sale at Olynthus," TAPA 59, pp. 225232

- 1931. "New Inscriptions from Olynthus and Environs," TAPA 62, pp. 40-56.
1934. "Inscriptions from Olynthus, 1934," TAPA 65, pp. 103-137. . 1938. "Inscriptions from Macedonia, 1938,” TAPA 69, pp. 43-76.

Rotroff, S. I. 1978. "An Anonymous Hero in the Athenian Agora," Hesperia 47, pp. 196-209.

Rouse, W. H. D. [1902] 1975. Greek Votive Offerings: An Essay in the History of Greek Religion, repr. New York.

Schattner, T. 2001. "Griechische und Grossgriechisch-Sizilische Hausmodelle," in "Maquettes architecturales" de l'antiquité: Regards croisés (Proche-Orient, Egypte, Chypre, bassin égéen, et Grèce, du néolithique à l'époque hellénistique). Actes du Colloque de Strasbourg, 3-5 décembre 1998 (Travaux du Centre de recherche sur le Proche-Orient et la Grèce antiques 17), ed. B. Muller, Paris, pp. 161-209.

Siebert, G. 1973. "Mobilier délien en bronze," Études déliennes (BCH Suppl. 1), pp. 554-587.

Siewert, P. 1996. "Votivbarren und das Ende der Waffen- und Geräteweihungen in Olympia," $A M 111$, pp. 141-148.

Ténos II = R. Étienne, Ténos et les $C y$ clades du milieu du $I V^{e}$ siècle av. J.-C. au milieu du III siècle ap. J.-C. (Ténos II), Athens 1990.

Themelis, P. 1979. “Ausgrabungen in Kallipolis (Ost-Aetolien), 19771978," AAA 12, pp. 245-279.

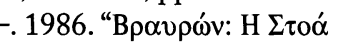

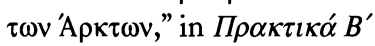

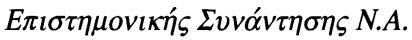

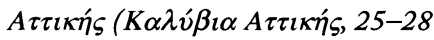

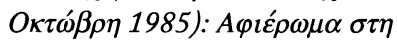
$\mu v \eta \mu \eta \eta \Delta . \Lambda \alpha \zeta \alpha \rho i \delta \eta$, ed. P. Philippou-Angelou, Kalyvia, pp. 225242.

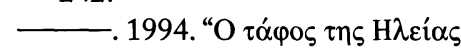
$\Phi \imath \lambda \eta \mu \eta \dot{v} v \alpha$," in $\Gamma^{\prime} E \pi \iota \sigma \tau \eta \mu o v \iota \kappa \eta$

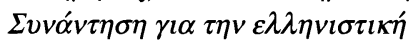

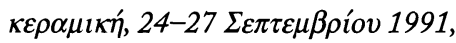

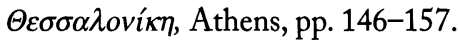

Thompson, H. A. 1940. The Tholos of Athens and Its Predecessors (Hesperia Suppl. 4), Athens.

Tomlinson, R. A. 1980. "Two Notes on Possible Hestiatoria," BSA 75, pp. 221-228. 
Tréheux, J. 1955-1956. “L'aménagement intérieur de la Chalkothèque d'Athènes," Études d'archéologie classique 1, pp. 133-146.

-1959. Études critiques sur les inventaires de l'indépendance délienne (diss. Paris).

1992. Inscriptions de Délos:

Index 1: Les étrangers, à l'exclusion des Athéniens de la clérouchie et des Romains, Paris.

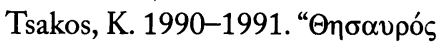

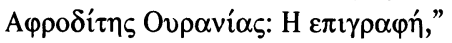
Horos 8-9, pp. 17-28.

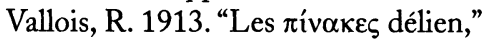
in Mélanges Holleaux: Recueil de mémoires concernant l'antiquité grecque offert à Maurice Holleaux en souvenir de ses années de direction à l'École française d'Athènes (1904-1912), ed. A. Picard, Paris, pp. 289-299.

Wace, A. J. B. 1948. "Weaving or Embroidery?” AJA 52, pp. 51-55. Wilhelm, A. 1974. Akademieschriften zur griechischen Inschriftenkunde (1895-1951), 3 vols., Leipzig.

\section{Dimitra Andrianou}

\section{National Hellenic Research Foundation}

48 VASILEOS KONSTANTINOU AVENUE

II 635 ATHENS

GREECE

dandrianou@hotmail.com 